\title{
تصور مقتر ح لتربية الفئات المهمشة في ضوء بعض الاتجاهات الحديثة
}

\author{
إعداد \\ د/ عزه أحمد صسادق علي \\ أستاذ أصول التربية والتخطيط التربوي المساعد الدمادي علدي \\ كلية التربية بقنا - جامعة جنوب الوادي \\ azasadek201941@yahoo.com \\ azza.ali@edu.svu.edu.eg
}




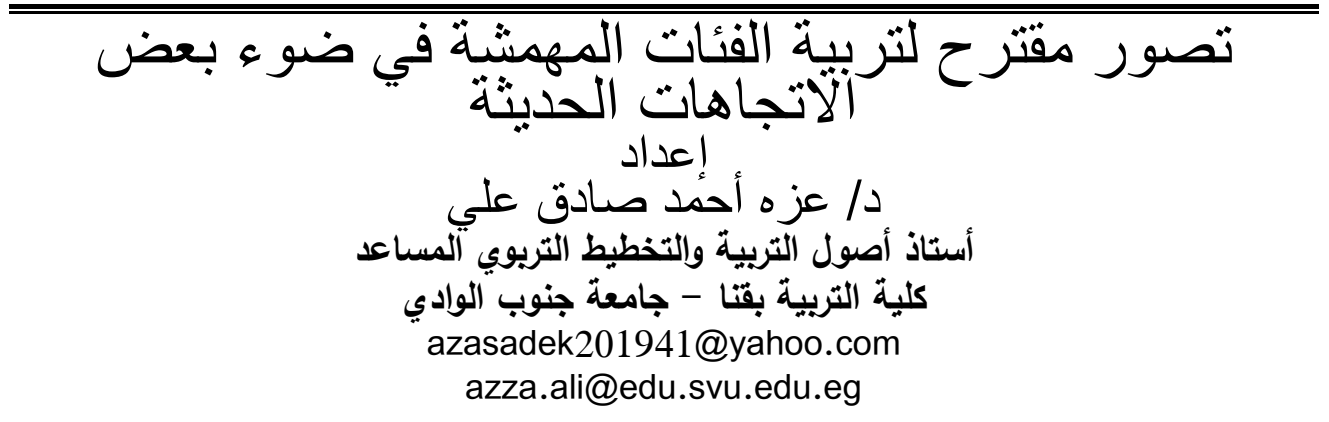

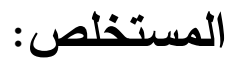

استهدف البحث إلقاء الضوء على مفهوم الفئات المهيشة، مظاهر التهميش وأنواعه،

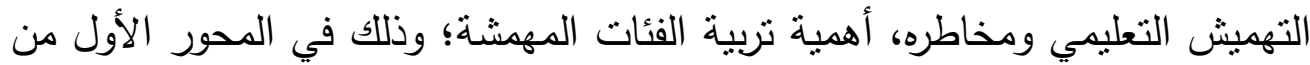
البحث، كذلك استهدف البحث عرض لبعض الاتجاهات الحديثة في مجال تربية الفئات

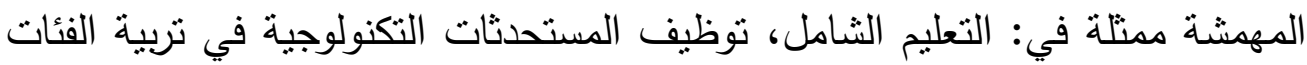

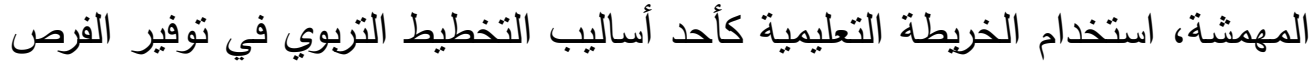

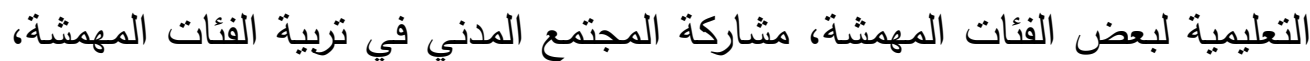

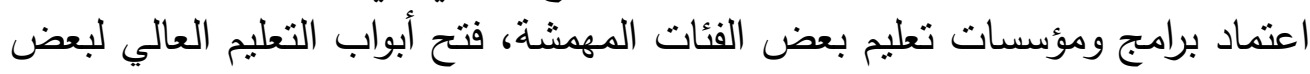

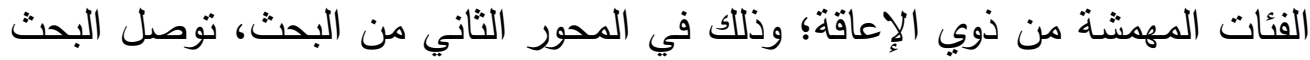
إلى عدة نتائج من أهمها: يعد التعليم الثامل أحد الإتجاهات ودلات الحديثة في مجال تربية

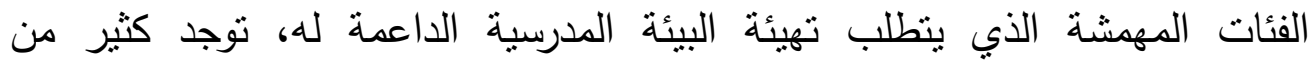

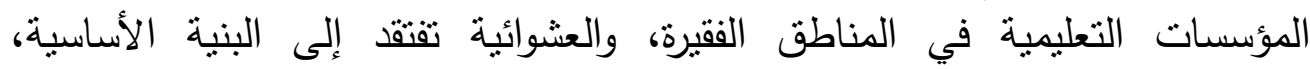

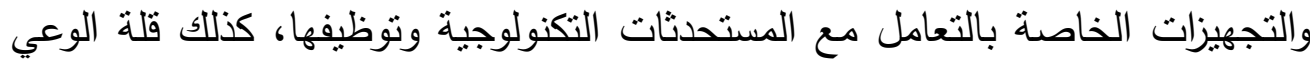

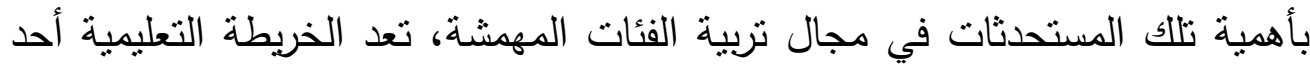

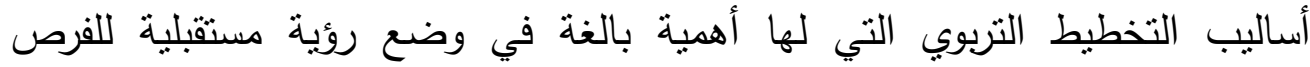
التعليمية وإتاحتها للفئات المهشية، يشير واقع المجتمع المصري لعدي لعدم كفاية الجهد الحكومي في مكافحة الفقر وصور التهميش المختلفة التي يعاني منها، تزايد الاهنمام في العقدين الأخيرين من القرن العثرين بجودة مؤسسات التعليم بصفة فئة عامة

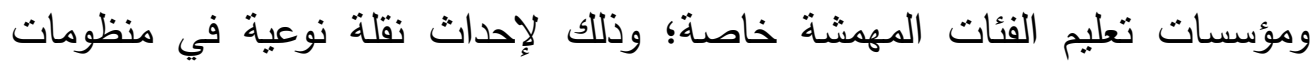

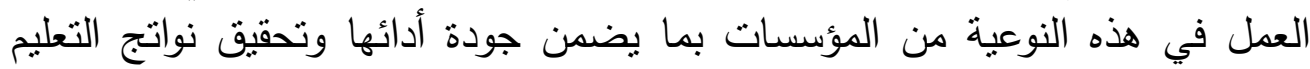

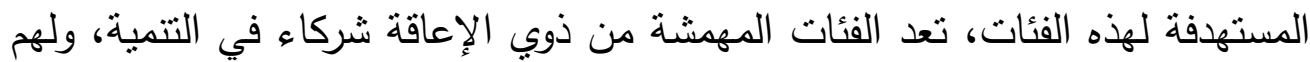

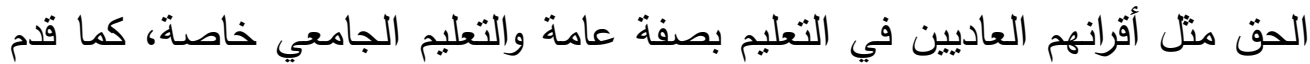

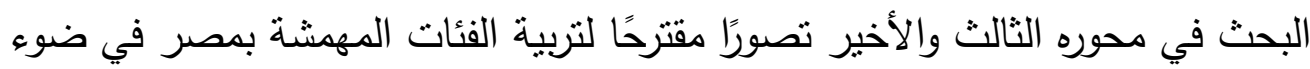
بعض الاتجاهات الحديثة. الكلمات المفتاحية: الفئات المهئة، المئة، الاتجاهات الحديثة. 


\title{
A proposed Concept For The Education of Marginalized Groups In The Light of Some Recent Trends
}

\author{
Dr. Azza Ahmed Sadek Ali \\ Assistant Professor of Education and Educational Planning \\ Faculty of Education in Qena - South Valley University \\ azasadek201941@yahoo.com \\ azza.ali@edu.svu.edu.eg
}

\begin{abstract}
:
The research aimed to shed light on the concept of marginalized groups, the manifestations and types of marginalization, educational marginalization and its risks, the importance of education for marginalized groups, in the first axis of the research, The research also targeted a presentation of some recent trends in the field of education for marginalized groups represented in: inclusive education, employing technological innovations in the education of marginalized groups, using the educational map as one of the methods of educational planning in providing educational opportunities for some marginalized groups, the participation of civil society in the education of marginalized groups, adoption Programs and institutions for the education of some marginalized groups, opening the doors of higher education to some marginalized groups with disabilities, in the second axis of the research, The research reached several results, the most important of which are: comprehensive education is one of the recent trends in the field of education for marginalized groups, which requires creating a supportive school environment for it. Also, the lack of awareness of the importance of these innovations in the field of education for marginalized groups. The educational map is one of the educational planning methods that are of great importance in setting a future vision for educational opportunities and making them available to marginalized groups, The reality of the Egyptian society indicates the insufficiency of the governmental effort to combat poverty and the various forms of marginalization that it suffers from, the increasing interest in the last two decades of the twentieth century in the quality of educational institutions in general and the education institutions of marginalized groups in particular; It guarantees the quality of its performance and the achievement of targeted educational outcomes for these groups. The marginalized groups with disabilities are development partners, and they have the right, like their regular peers,
\end{abstract}


to education in general and university education in particular, In addition, a proposed concept for the education of marginalized groups in Egypt has been presented in the light of some recent trends.

Keywords: Marginalized groups, recent trends.

\section{مقدمة}

نتيجة لزيادة الوعي بأهمية توفير الرعاية والتعليم للجميع فقد شهر القرن

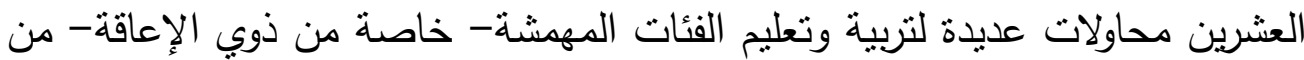
قبل الحكومات المتعاقبة والمنظمات الدولية والمحلية والجمعيات الخيرية، كما تم التأكيد من قبل المسئولين بوزارات التربية والتعليه، والثئون الاجتماعية، والتقافة، والثباب والرياضة، والباحثين في مجال العلوم الإنسانية على أهمية تربية وتعليم الفئات المهششة في نطاق السياق التعليمي والتقني والاجتماعي الذي تشهده الألفية الثالثة. فقد اهتمت مصر بهذه الفئات تشريعيًا، حيث أصدرت عديدًا من القرارات

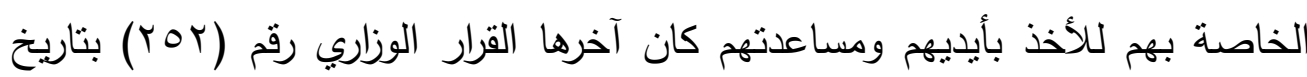

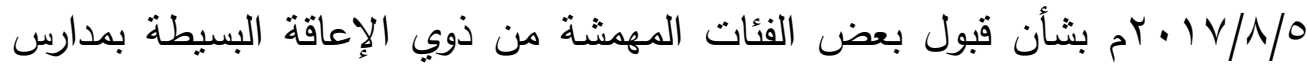

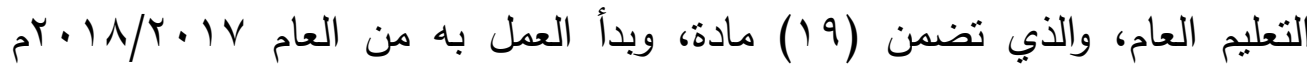
(جمهورية مصر العربية: وزارة التربية والتعليم: V V • rم).

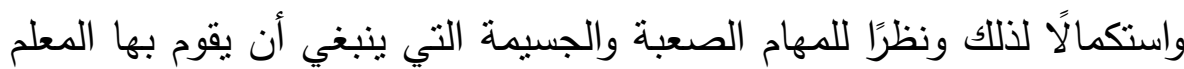
في تربية وتعليم تلكك الفئات فقد نال إعداده وتدريبه اهنمامًا كبيرًا، وتمنل ذلك في فتح برامج التربية الخاصة وتعليم الكبار على مستوى التعليم الجامعي؛ مما يمثل خطوة هائلة في إعداد المعلم المتخصص الذي برغب في العمل مع تللك الفئات عن حب ومن منظور إنساني. واستكمالًا لاهتمام القيادة العليا في مصر بهذه الفئات من ذوي الاحتياجات الخاصة اعثبر عام 11 إبم عامًا لهم. وفي مجال نربية الفئات المهيشة عقدت عديد من الندوات والمؤتمرات، التي أوضحت جميعها أن هناك تفاونًا في عوامل كثثرة، وشدة تباين بين الناس التي تتلقى

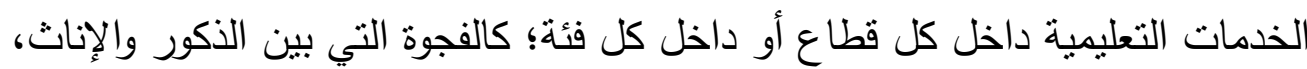


بين المعاقين والعاديين، وبين العاديين وذوي الاحتياجات الخاصة، وبين الأغنياء والفقراء، وبين الأطفال أصحاب الظروف العادية والأطفال ذوي الظروف القاسية؛ كأطفال الشوارع، والأطفال العاملين، وغيرها من الفئات التي تحتاج إلى أن تصل

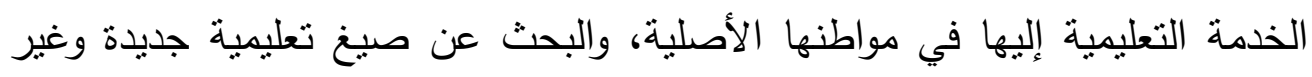
تقليدية لتوصيل الخدمة التعليمية لهذه الفئات أينما كانت ومهما كانت قدراتها. كان آخر هذه المؤتمرات: المؤتمر العلمي الثامن (الدولي الرابع) لكلية التربية،

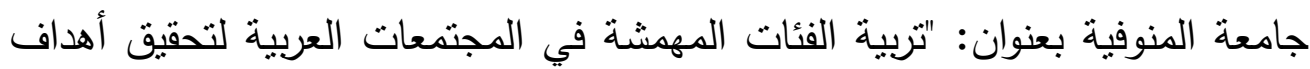
التتمية المستدامة- الفرص والتحديات" والذي جاء انطلافًا لما تشهده المنطقة العربية من مظاهر تشير إلى وجود خلل في تطبيق مبدأ العدالة والحق في التعليم وتكافؤ الفرص التعليمية وإتاحته للجميع بصور وأثنكال تراعي الظروف المختلفة لأفراده، بالإضافة إلى صور الحرمان وعدم التكافؤ التي تصل إلى حد وصف البعض لها بالتهميش والإقصاء وأحيانًا تصل إلى الاستبعاد لبعض الفئات بالمجتمع ( جمال علي الإني

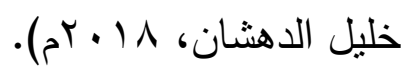
هذ بالإضافة إلى أن معظم البلدان العربية تواجه تحديات لا تحقق تكافؤ الفرص للجميع في الحصول على التعليم، وغالبًا ما تغيب الفئات المهمشة عن دوائر اهتمام السياسات التعليمية الوطنية، مما يحرم كثير من الناس من حقهم في التعليم (صبحي شعبان شرف: 11 ( • rم).

لذا يجيء هذا البحث ليلقي الضوء على أهمية تربية الفئات المهمشة، وتوعية

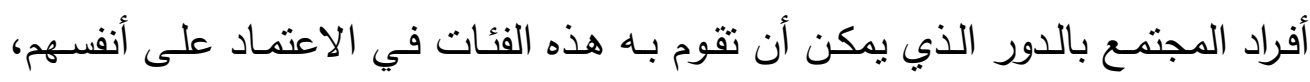

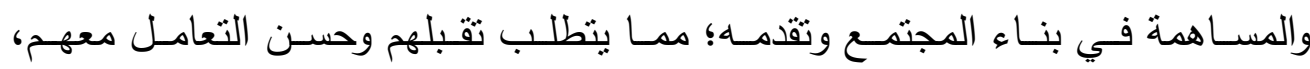
وتشجيعهم على الاندماج مع بقية أفراد المجتمع.

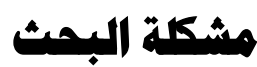

على الرغم من الجهود المبذولة في مجال تربية الفئات المهيثة إلا أنها لا تتناسب مع أعداد الفئات المهمشة، ومتطلبات توفير فرص التربية والتعليم المناسبة 
لظروف وإمكانيات هذه الفئات المهمة من نسيج المجتمع المصري بحضارته العريقة الممتدة لآلاف السنين.

ففي مجال تربية الفئات المهيثة من الأميين أشارت الإحصاءات إلى أن نسبة

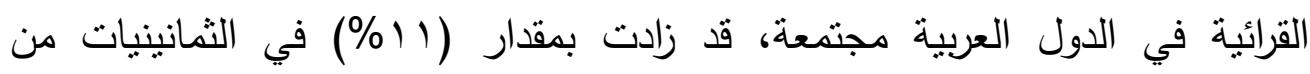

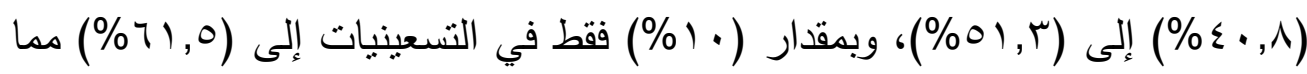
يعني أن العقد الأخير لم يكن مختلفًا عن العقد الذي سبقه، وأن إعلان جومتيان لم يؤد إلى تغييرات جدية في إنجاز الدول العربية في موضوع الأمية، وأن الهدف المقرر

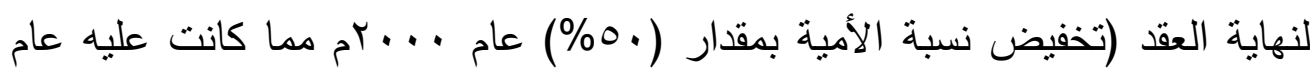

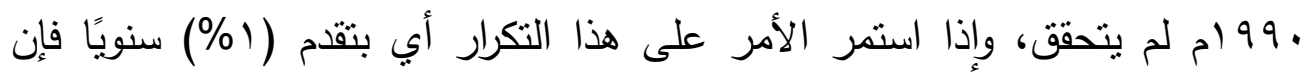
الدول العربية مجتمعة سوف تحتاج إلى (9) سنة للقضاء على الأمية (اليونسكو:

$$
\text { . (70 6 r... }
$$

هذا من ناحية الإحصاء الرقمي، أما من حيث النوعية، يلاحظ أن برامج محو الأمية لا تزال تقليدية في طبيعتها مما يؤدي إلى عزوف المستهدفين عن المشاركة فيها؛ فالمناهج في الغالب هي مناهج التعليم الابتدائي، والمعلمون هم معلمو التعليم الابتدائي أو العاطلون عن العمل والحاصلون على الثانوية العامة، وطرائق التدريس هي الطرائق المستخدمة في التعليم التقليدي، ومن ثم هناك حاجة ماسة إلى إعادة نظر جذرية في استراتيجية العمل الميداني في مجال محو الأمية وتحسين الكفاية الداخلية

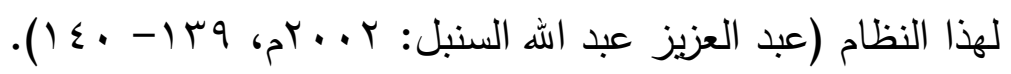
وفي مجال الاهتمام بتربية الفئات المهمشة من الموهوبين في مرحلة رياض الأطفال بوجه خاص، ما بزال اهتمامًا ضعيفًا كمًا ونوعًا، ولا تتوافر رعاية خاصة لهنة

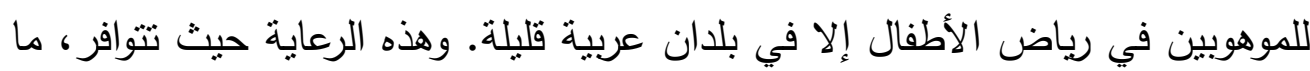
تزال في بدايتها، ولا تستتد إلى الدراسات العلمية والتجارب الحديثة في هذا المجال إلا لإي في قليل من هذه البلدان (المنظمة العربية للتربية والثقافة والعلوم: . . . بم، ror). ولا يختلف هذا الواقع في المراحل المختلفة من التعليم؛ فالمساحة المخصصة لتربية الفئات المهشة من الموهوبين والمبدعين ما زالت محدودة للغاية حتى في 
الجامعات العربية التي اكتفى بعض من فيها بإنشاء أندية بسيطة في تركيباتها تحت

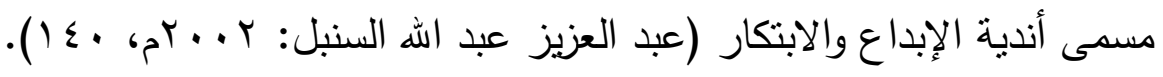
وفي مجال تربية الفئات المهمشة من الأطفال المعوقين: تشير الإحصاءات

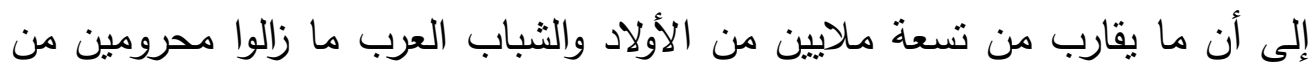

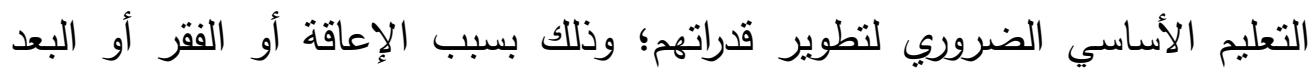
الجغرافي، أو المعاناة السياسية والاقتصادية، وأن معظم الخدمات التربوية القائمة في عديد من الدول العربية تقوم بها مؤسسات متخصصة تعمل خارج التيار التعليمي العام. وتبلغ نسبة المستفيدين من هذه الخدمات (0\%) من مجموع الفئات المهشة

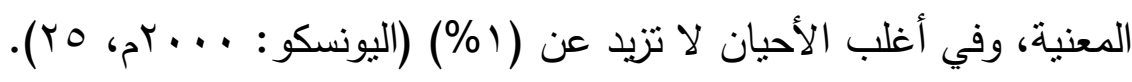

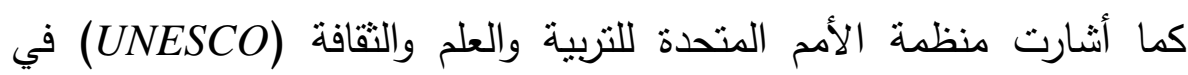

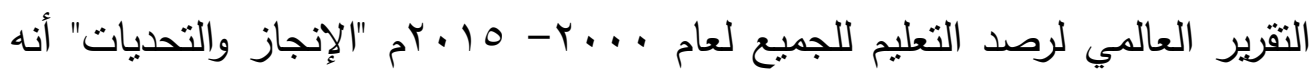

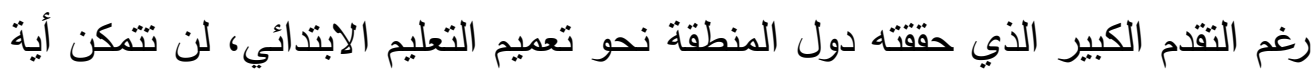
دولة عربية- ما عدا تونس- من تحقيق هدف التعليم للجميع المتمنل بضمان إكمال

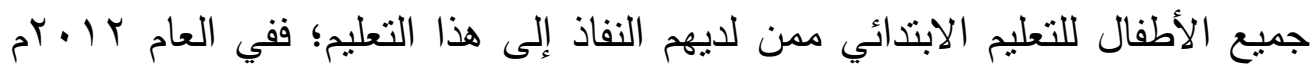
كانت لا تزال المنطقة تعد (ـ,0) مليون طفل في سن المدرسة الابتدائية خارج المدرسة، وكان لا يزال توفير التعليم الجيد بحاجة إلى اهتمام خاص، ولاشك في أن

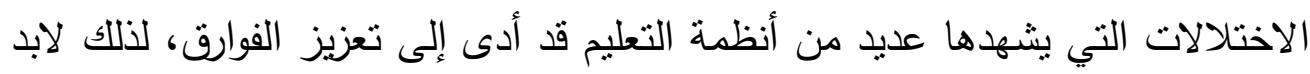
من تدارك هذا الأمر في الوقت الذي يقوم فيه العالم بوضع أجندة جديدة للتعليم، حتى لتى لهن يتمكن الأطفال والثباب والكبار على حد سواء من الاستفادة من الفرص التي يوفرها التعليم بغض النظر عن الظروف التي ولدوا أو عاشوا عليها (منظمة الأمم المتحدة الأه

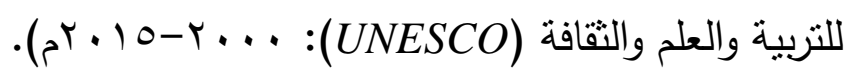

وعلى ضوء هذا الواقع توجد عديد من المنطلقات التي تتطلب التعرف على

واقع الفرص التعليمية المتاحة للفئات المهشة في مصر، من هذه المنطلقات: 
1- الفئات المهشة تتواجد في المجتمعات الإنسانية بشكل عام- أيًا كان درجة

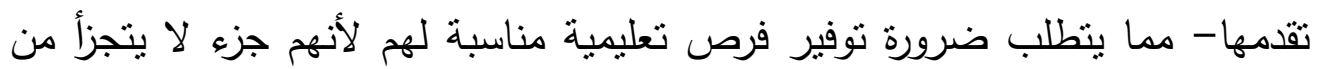
نسيج المجتمع. ץ- وجود فجوة اقتصادية واجتماعية وتعليمية بين أبناء المجتمع المصري، مما يمثل

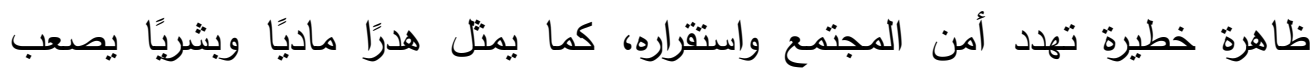
تعويضه مستقبلًا. ب- تحقيق العدالة التربوية والمساواة الثاملة في فرص التعليم بين أبناء المجتمع الواحد كمطلب أساسي لتحقيق التتمية الثاملة وتعويض الفئات المحرومة والمهشئة. ع- وجود رغبة حقيقية لدى كثيرين على المستويين المحلي والعالمي لدمج الفئات المهشة للعيش معًا في مجتمع واحد متجانس من أجل تحقيق التكامل الاقتصادي والاجتماعي. 0- إجراء مزيد من البحوث والدراسات عن الاتجاهات والمداخل الحديثة في مجال تربية الفئات المهمشة، ومحاولة تطبيقها والاستفادة منها في تربية هذه الفئات، حتى يتم تغيير وضعهم الاجتماعي والاقتصادي والارتقاء بهم لمستويات حياتية أفضل. لذا تحددت مشكلة البحث الحالي في التساؤلات الآتية:

\section{تصاؤلات البمث:}

1- ما الإطار المفاهيمي لتربية الفئات المهشةٌ؟

r- ما الاتجاهات الحديثة في مجال تربية الفئات المهمثة؟ r- ما التصور المقترح لتربية الفئات المهشة بمصر في ضوء بعض الاتجاهات

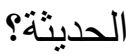

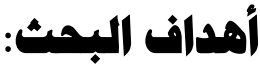

$$
\text { هدف البحث الحالي إلى: }
$$

1- التعرف علي الإطار المفاهيمي لتربية الفئات المهمشة. r- إلقاء الضوء على بعض الاتجاهات الحديثة في مجال تربية الفئات المهيثة. 
r- تقديم تصور مقترح لتربية الفئات المهشة بمصر في ضوء بعض الاتجاهات الحديثة.

نبعت أهمبة البحث الحالي من الاعتبارات الآتية:

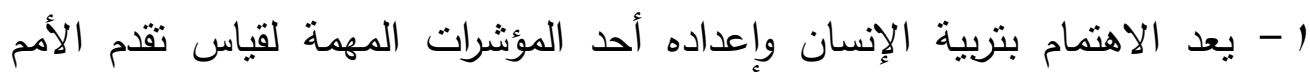
والثعوب، لأنها المدخل الرئيس والمقوم الأساس لبناء الدولة العصرية الحديثة، ولعل الإه

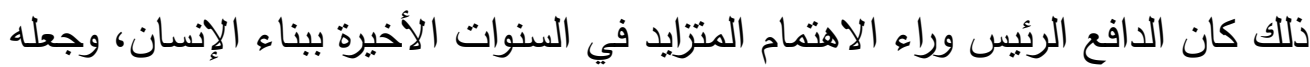
هدفًا أسمى يتم السعي لتحقيقه بكافة الوسائل. r- التتمية الثاملة لأي مجتمع من المجتمعات تتحقق بمشاركة جميع أبنائه، بغض

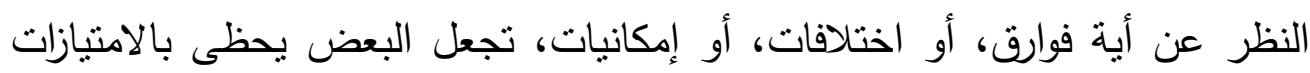
والحقوق، وتحرم الفئات المهمشة من تلك الامتيازات والحقوق خاصة في مجال التعليم.

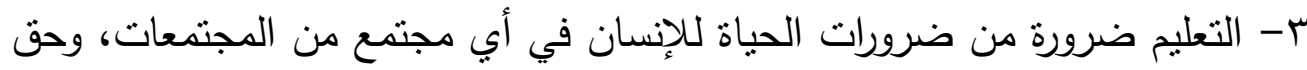
من الحقوق الأساسية التي نصت عليها المواثيق الدولية؛ كالإعلان العالمي لحقوق الإنسان، وكذلك نصت عليها اتفاقيات معظم الدساتير باعتباره حق أصيل، والتزام من الحكومات تجاه مواطنيها. ع - جذب نظر المسئولين عن التعليم لأهمية تبني بعض الاتجاهات الحديثة في مجال تربية الفئات المهمشة، التي من خلالها بمكن توفير فرص تعليمية ملائمة وذات جودة لهذه الفئات، والبحث عن صيغ التعليم المختلفة التي بمكن بواسطتها توصيل الخدمة التعليمية لهذه الفئات أينما وجدت، وكذللك حث منظمات المجتمع المدني على ضرورة المشاركة بفاعلية في تربية هذه الفئات.

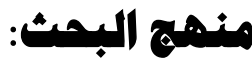

لتحقيق أهداف البحث الحالي تم استخدام المنهج الوصفي، باعتباره أكثر ملائمة؛ بما يتيحه من جمع للبيانات والمعلومات وتحليلها؛ للتعرف على الاطار المفاهيمي لتربية الفئات المهمشة، الاتجاهات الحديثة في مجال تربية الفئات المهشةة، 
ومن ثم تقديم تصور مقترح لتربية الفئات المهمشة بمصر في ضوء بعض الاتجاهات الحديثة.

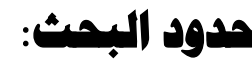

اقتصر البحث على دراسة الإطار المفاهيمي لتربية الفئات المهمشة من حيث:

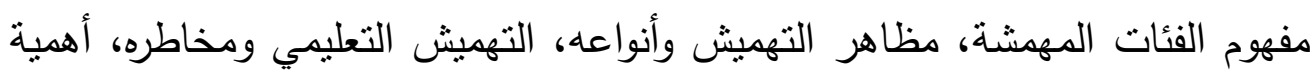
تربية الفئات المهيشة.

واقتصر البحث في تتاوله لبعض الاتجاهات الحديثة في مجال تربية الفئات

المهشة على كل من: التعليم الشامل، توظيف المستحدثات التكنولوجية في تربية الفئات المهمشة، استخدام الخريطة التعليمية كأحد أساليب التخطيط التربوي في توفير الفرص التعليمية لبعض الفئات المهمشة، مشاركة المجتمع المدني في تربية الفئات المهشة، اعتماد برامج ومؤسسات تعليم بعض الفئات المهيشة، فتح أبواب التعليم العالي لبعض الفئات المهيشة من ذوي الإعاقة.

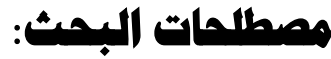

فيما يأتي تعريف بمصطلحات البحث إجرائيًا:

\section{ا الفئات المهمشية: The Marginalized Groups}

تعرف الفئات المهشة إجرائيًا في هذا البحث بأنها: تلك الفئات المستضعفة والأكثر احتباجًا والأولى بالتربية من الأطفال والثباب والمسنين والنساء، الذين يتم

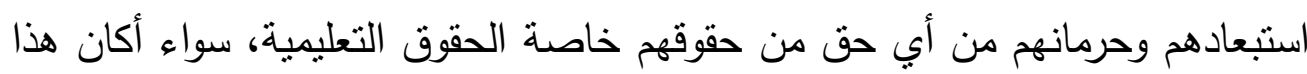

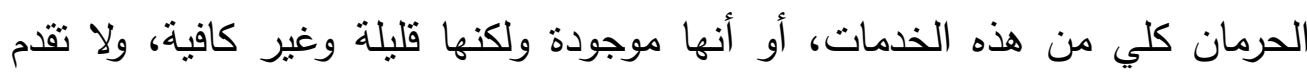
بالثكل الذي يتلاءم واحتياجات هذه الفئات.

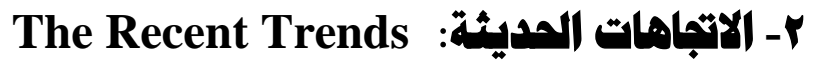

تعرف الاتجاهات الحديثة إجرائيًا في هذا البحث بأنها: المداخل والأساليب التي

بدأت كثير من الدول تطبيقها سواء على المستوى العالمي أو الإقليمي؛ وذللك في محاولة جادة لتوفير فرص تعليمية ذات جودة للفئات المهمشة من أبناء المجتمع. 
حتى يحقق البحث أهدافه وللإجابة عن تساؤلاته فإن البحث سار وفق

$$
\text { الخطوات الآتية: - التية }
$$

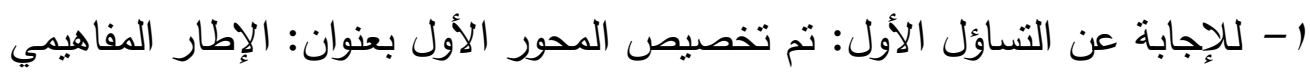

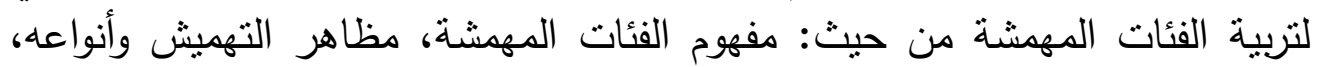

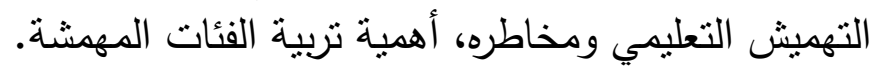

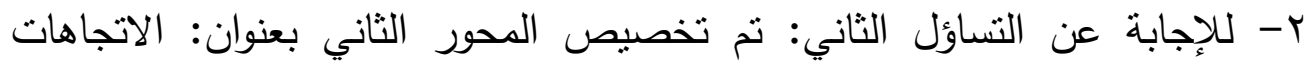

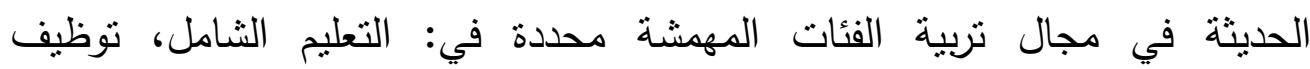

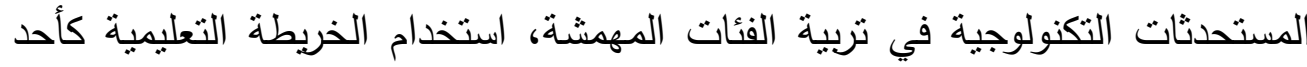
أساليب التخطيط التربوي في توفير الفرص التعليمية لبعض الفئات التئن المهيشة، مشاركة

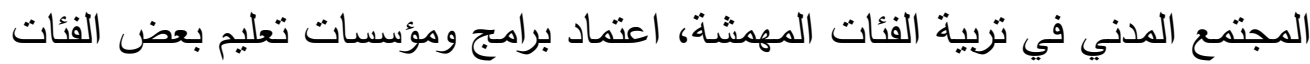

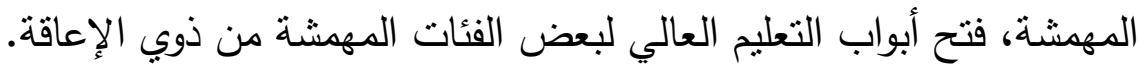
ץ- للإجابة عن التساؤل الثالث: تم تقديم نتائج البحث، تصور مقترح لتربية الفئات المهشة بمصر في ضوء بعض الاتجاهات الحديثة، كما نم تقديم مجموعة من

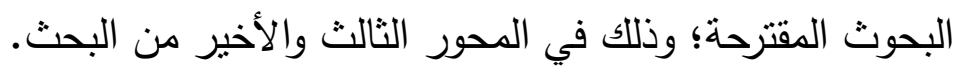

\section{الإطار النظثري لالبمث}

في ضوء تعدد الفئات المهشةة، وقلة تفعيل برامج الرعاية المقدمة لبعض هذه

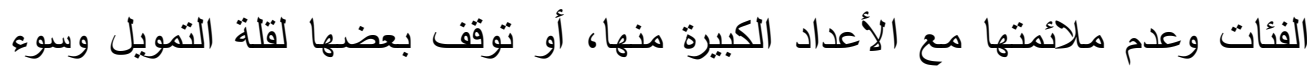
الإدارة، وغيرها من العوامل يتضح أن الإحاطة بكل جوانب هذه القضية تتصدره مشكلات متعددة تتعلق بنمط المعلومات المتاحة ونوعيتها ومعايير قياس التهميش ومؤشراته، كما يتضح صعوبة حصر وتتاول جميع أنواع التهميش، التي يصعب ومبن الفصل بينها إلا أنه لابد من إزالة جميع المعوقات التي تحول دون حصول الأفراد على حقوقهم وفرصهم الكاملة في شتى مجالات الحياة وخاصة التعليم الذي هو أساس التماسك الاجتماعي بين أفراد المجتمع الواحد ومن ثم تحقيق العدالة الاجتماعية والرفاهية لجميع أفراده بما ينعكس بالإيجاب على أمن المجتمع واستقراره. 
لذا يعد التهميش التعليمي من أخطر أنواع التهميش لأنه يؤدي إلى أنواع

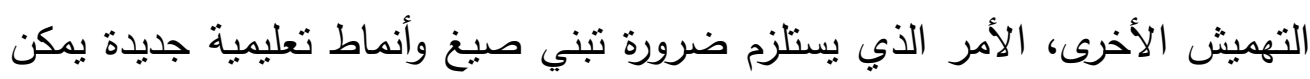
من خلالها توفير فرص التعليم المختلفة لهذه الفئات، وتحسين الفرص التعليمية المقدمة لبعض الفئات الأخرى، وكذلك البحث عن مزيد من الاتجاهات الحديثة في مجال تربية الفئات المهوشة ورعايتها. وبتبلور الإطار النظري للبحث الحالي في الدحاور الآتبة:

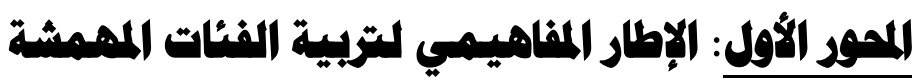

كثرت الدراسات التي تتاولت مفهوم الفئات المهمشة بصورة يصعب معه حصرها، كما كثرت المؤتمرات التي تتاولت هذه الفئات- خاصة في مجال التربية الخاصة، والصحة النفسية، وعلم النفس، والمناهج وطرق التدريس، وأصول التربية، وعلم الاجتماع، والقانون، والسياسة، وغيرها- وقبل تفصيل الحديث عن أهمية تربية

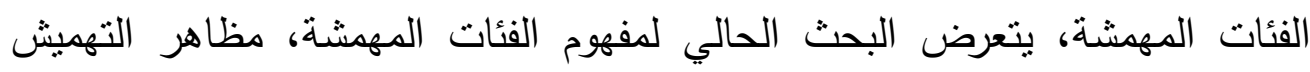
وأنواعه، التهميش التعليمي ومخاطره، وذلك على النحو الآتي:

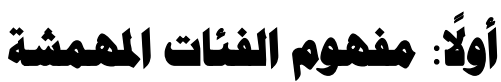

يعد مفهوم الفئات المهشة من أكثر المفاهيم صعوبة وتعقيدًا في مجال العلوم الإنسانية بصفة عامة والتربوية خاصة؛ لأنه يتضمن فئات عديدة يصعب حصرها والاتفاق عليها.

وبالرجوع إلى المعنى اللغوي لكلمة "الفئة" يتضح أنها تعني الطائفة أو الفرقة

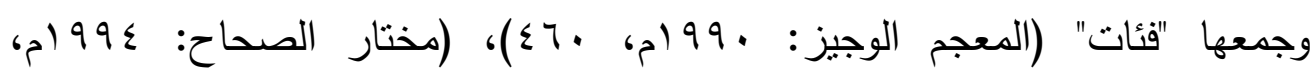
.$(0) 7$ أما عن الأصل اللغوي لكلمة "همش"، فيقال همش الرجل همثًا أي كثر الكلام

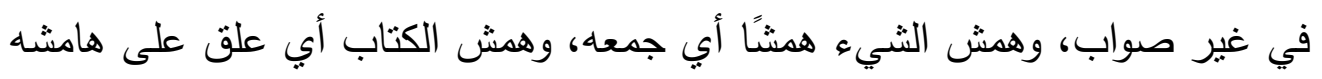

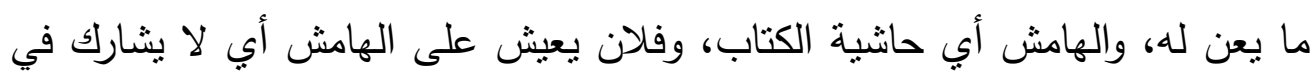

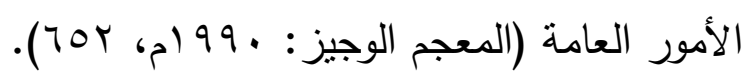


وبالنظر إلى المفهومين السابقين يتضح أن كلمة التهميش تطلق على الفئات

التي تعاني من الاستبعاد الاجتماعي والحرمان الاقتصادي والنفسي والسياسي، مما يولد للديهم الثعور بالعجز وكراهية الآخرين.

وفي التسعينيات لمع مفهوم الاستبعاد الاجتماعي، إذ شاع استخدامه في القارة

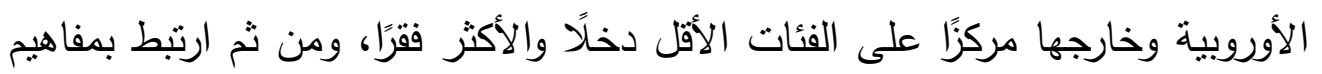

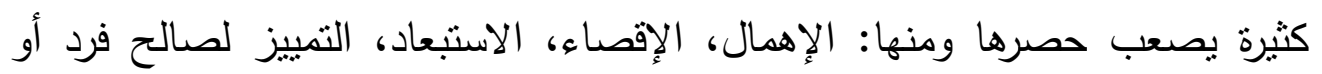

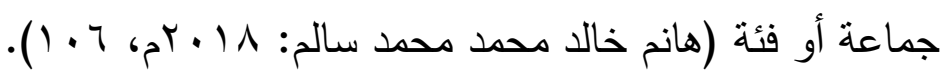
كما يقصد بالتهميش وضع العوائق التي تمنع الأفراد أو الجماعات أو فئات معينة من الحصول على الفرص والموارد والحقوق المتاحة طبقًا لظروفه وإمكانياتهم وقدراتهم منساويين في ذلك مع بقية الأفراد مما يجنبهم الحرمان والفقر واليأس ويحقق لهم العدالة الاجتماعية. كما يعرف التهميش بأنه: مجموعة من المعتقدات والآراء والإجراءات التي يتم من خلالها تقسيم المجتمع الإنساني إلى فئات وطوائف وتوجيهه لصالح ثلاك الفئات

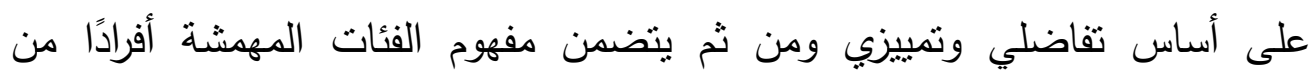
مستويات اقتصادية واجتماعية وثقافية متتوعة وبيئات وأعراف ولغات وأجناس مختلفة، ومستوى قدرات واحتياجات متباينة؛ كذوي الإعاقة والموهوبين وأطفال الشوارع وأطفال بلا مأوى والأطفال العاملين والمشردين واللاجئين والأيتام والفقراء والمحتاجين

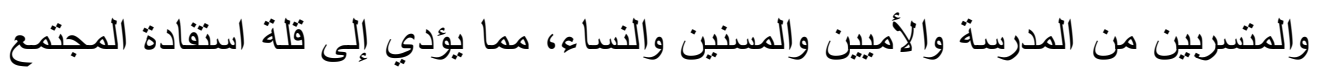

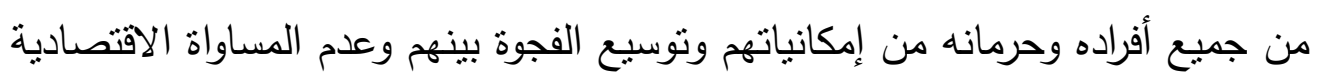
والاجتماعية والسياسية وعدم الحصول على فرص التعليم والترقي الاجتماعي (هانم

$$
\text { خالد محمد محمد سالم: } 1 \text { ( • (بم، } 7 \text { • ( ). }
$$

والحق أن وجود هذه الفئات ضمن النسيج الاجتماعي لا يعني أن الفرد منهم عاجز عجزًا كاملًا عن القيام بدوره، بل توجد لديه قدرات خاصة يمكن استثمارها إذا ما لاه قدمت له فرص التربية التي تصل بهم إلى أقصى درجات الإنجاز ، شأنهم شأن بقية أفراد المجتمع الأسوياء. اك. 
ويكمن التحدي الحقيقي للتربية عامة في أن تمكن الجميع - بلا استثتاء- من

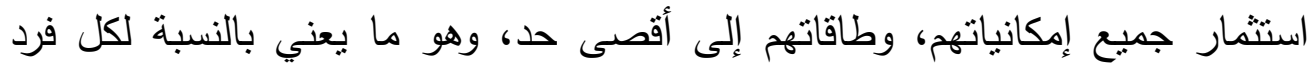
شحذ قدراته الذاتية، والاستمتاع بحقوقه، والمشاركة في تتمية مجتمعه، فيكون الجميع

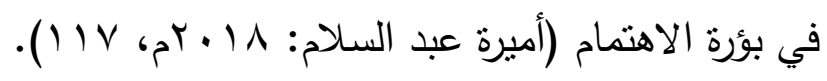

ويقصد بالتهيش بصفة عامة الإجراءات العلنية أو التوجهات البشرية التي

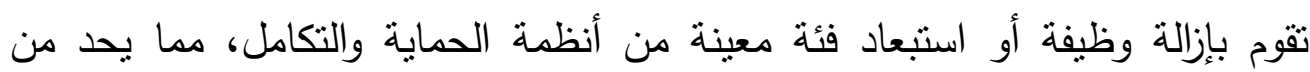
الفرص المتاحة لها، حيث يمثد التهميش ليشمل الجوانب الاجتماعية والاقتصادية

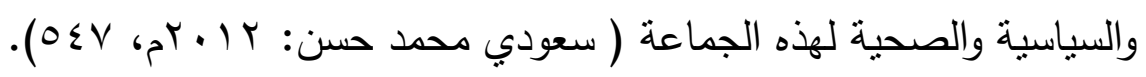

وتعرف الفئات المهشة من الأطفال على أنها: فئة الأطفال الذين يتم تركهم أو

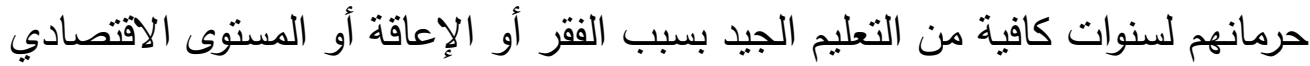

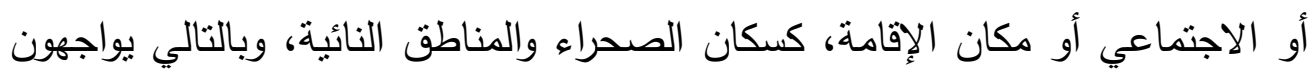
فرصًا أقل من المستوى للحصول على وظائف آمنة، ومستوى لائق من الحياة،

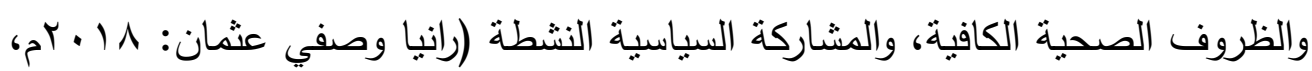

$$
\text { . (rVT-tre }
$$

وتعرف الفئات المهشة من الفتيات بأنها: الفتيات اللاتي تعانين من أي مظهر

من مظاهر الإهمال والحرمان من التعليم بدرجة تفقدا حقوقها كمواطنة منساوية مع باقي أفراد المجتمع وتجعلها مستبعدة ومنعزلة، سواء أكان هذا الحرمان من التعليم بسبب ظروف اقتصادية أو مكانية (جمال علي خليل الدهشان، أماني محمد شريف

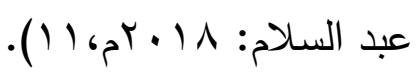

كما تعرف الفئات المهيشة على أنها: فئة أو جماعة من الأفراد يتم استبعادهم

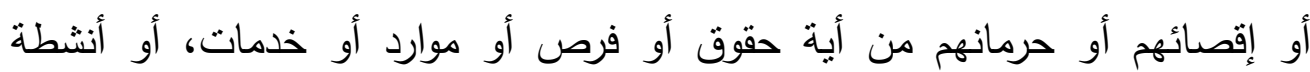

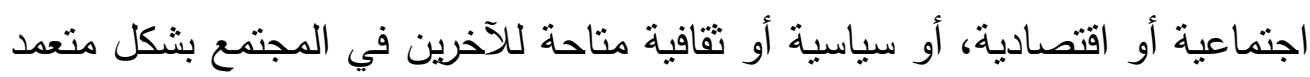

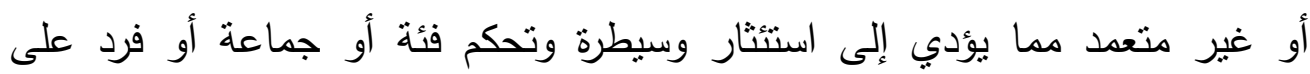
الآخرين، ومن ثم يفتقد المجتمع إلى المساواة والعدالة بين أفراده وينتقص من حقوقهم، 
ويهدد إنسانيتهم وكرامتهم، مما يولد لديهم الثعور بالعجز والحرمان والعدالة (هانم خالد

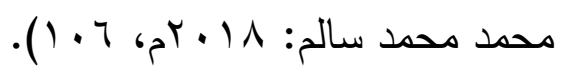

كما أن الأطفال الموهوبين يمثلون شريحة على درجة كبيرة من الأهمية، وأنهم

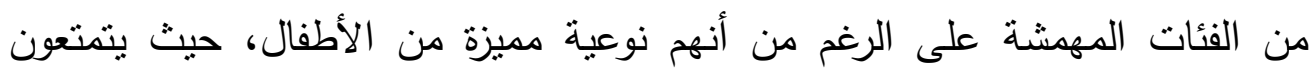
باستعدادات وقدرات عقلية وإبداعية عالية.

وربما ينظر لهذه الفئات على أنها من الفئات المهمشة لأنهم لا يوجه إليهم اهتمام كاف من المؤسسات التعليمية والمجتمعية، على الرغم من كونهم ركيزة أساسية للتتمية، والتقدم، ووسيلة فعالة لتحديث المجتمع، وتطويره، ومنطلقًا لمواجهة تحديات المستقبل وطموحاته، وقاطرة التقدم والتطور في المجتمع (أحمد الطيب محمد، آخرون: .$(9 \leq 6, r \ldots \leq$

كذلك فئة الأطفال المهشة من سكان المناطق العشوائية التي نشأت بشكل غير رسمي أو قانوني، وعلى أرض غير مخصصة للبناء، وبجهود ذاتية، دون تدخل

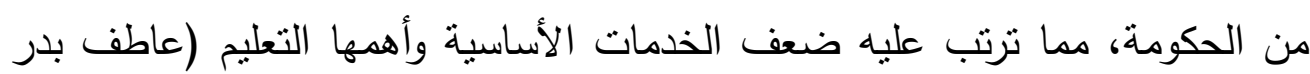

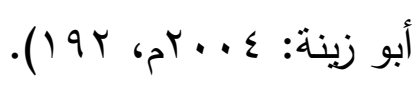

وتتصف هذه المناطق بمجموعة من الخصائص السلبية: كالازدحام والتكدس والتلوث البيئي، ونقص الخدمات الأساسية، كما يعد الطفل في تلأك المناطق من أثند

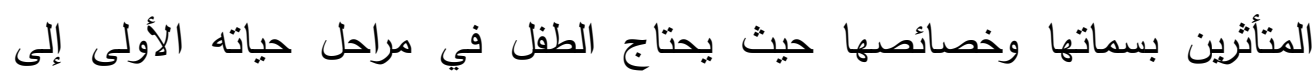
مجموعة من الخدمات تشبع احتياجاته الجسمية والنفسية والاجتماعية، وبالطبع فإن هذه الخدمات لا تتوافر بالشكل المناسب في تلك المناطق (محمود محمد عودة: ب. . r بم)؛ ومن ثم حرمان طفل المناطق العشوائية من الخدمات بصفة عامة والخدمات التعليمية خاصة.

كما تعد الأمية، وانخفاض المستوى الثقافي، والوعي المشوه أو الزائف من أهم الصفات العامة لسكان المناطق العشوائية، كذلك التهميش والاستبعاد والإقصاء الاجتماعي، الأمر الذي جعلهم محرومين من الخيارات المتاحة للآخرين، وتضيق 
أمامهم فرص الحياة الصحيحة وفرص تحقيق الذات (سلامة صابر محمد العطار،

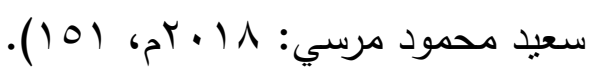

في ضوء ما سبق يمكن إطلاق مفهوم الفئات المهشة على الفئات المستضعفة والأكثر احتياجًا والأولى بالتربية من الأطفال والثباب والمسنين والنساء، الذين يتم استبعادهم وحرمانهم من أي حق من حقوقهم خاصة الحقوق التعليمية، سواء واء ولاء

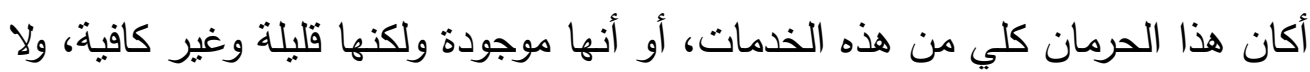
تقدم بالثكل الذي يتلاءم واحتياجات هذه الفئات.

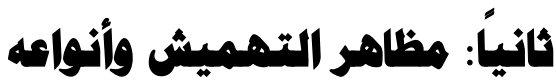

تتعدد مظاهر التهميش والإقصاء الاجتماعي في العالم العربي بين غياب الصفة القانونية، والتمبيز بسبب الجنس أو الهوية، والوضع الاجتماعي الهش، وعدم توافر سياسة شاملة تعني بذوي الاعاقات، وضعف الحقوق الاقتصادية والاجتماعية والمدنية والسياسية، وعدم توافر المأوى الآمن والخدمات الصحية الثاملة، وانتشار الأمية، والتشرد، وعدم توافر الحماية للعمال المهاجرين واللاجئين (محسن معوض: $\cdot(r) \sin (t)$

ومن ثم تتعدد الفئات المهيشة، كما أن الإحاطة بجميع جوانبها تتصدره مشكلات متعددة، تتعلق بنمط المعلومات المتاحة ونوعيتها ومعايير قياس التهميش ومؤشراته.

فالأدبيات الدولية والعربية تكاد تجمع على صعوبتها بصفة عامة وفي المنطقة العربية خاصة، لاسيما أن الفئات الاجتماعية ضحايا الإقصاء والتهميش غير مصنفة إداريًا، ولا تبرز في الإحصاءات الرسمية، وهي مشكلة تتصدر عديد من البحوث والدراسات المتخصصة.

كما أنه يوجد إجماع حول مجموعة من المؤشرات المرتبطة بقياس ظروف الحياة، لاسيما تلك المتعلقة بالسكان والعمل والتربية والصحة والسلع الاستهلاكية، والحصول على الخدمات، والعدالة، والدخل، وأوقات الفراغ، والاندماج الاجتماعي، غير أن تباين الأوضاع الاجتماعية والاقتصادية والسياسية بين بلد وآخر يجعل هذه 
المؤشرات غير متجانسة بين الدول العربية، مما بزيد من صعوبة اعتماد مقاربات

$$
\text { موحدة على الصعيد الإقليمي (محسن معوض: ب إ. rم، (Y). }
$$

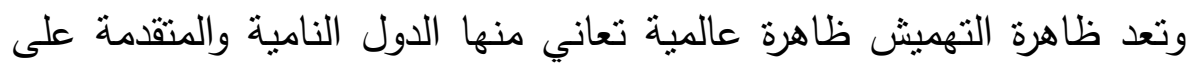

$$
\text { حد سواء لذا تتعدد أنواعه وأثنكاله. }
$$

فقد صنفت إحدى الدراسات الفئات المهشة على النحو الآتي (زينب محمود

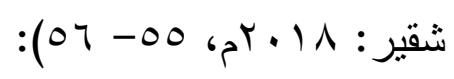

- ذوو المشكلات التعليمية: بطيبء التعلم- المتأخرين دراسيًا - ذوو صعوبات التعلم الموهوبون والمتقوقون - الطلاب المهملون بمؤسسات التعليم. r- ذوو المشكلات الحسية البسيطة: ضعاف السمع - ضعاف البصر • r- ذوو مشكلات التواصل: كل من مضطربي الكلام، والنطق، واللغة، والصوت. ع- ذوو الإعاقات الجسمية والعصبية: مرضى الثلل الدماغي، وشلل الأطفال،

$$
\text { والصرع، والبتز ، وغيرهم من المقعدين. }
$$

ه- ذوو الأمراض العضوية المزمنة: مرضى القلب المزمن، ومرضى الفشل الكلوي،

$$
\text { ومرضى السرطان. }
$$

צ- ذوو الاضطرابات السيكوسوماتية: اضطرابات الأكل، ومرضى القولون العصبي، وقرحة المعدة العصبي. V- ذوو الاضطرابات الانفعالية: اضطراب الانتباه المصحوب بفرط النشاط، ذوو الاضطرابات الانفعالية والسلوكية. ᄉ- المشكلات الاجتماعية: ذوو السلوك العدواني المرضي، ذوو النشاط الزائد، العنف، التخريب، سلوك التتمر ، التعصب. 9- المصابون بالأمراض النفسية بأنواعها.

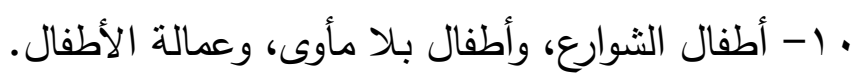
11 - كبار السن ممن حرموا من التعليم.

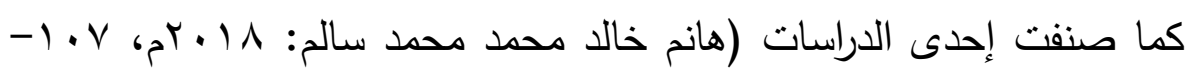
^ • ( ) التهميش إلى عدة أنواع: 
1- التهميش الاقتصادي: حيث تستحوذ فئة قليلة من المجتمع على النصيب الأكبر من الدخل القومي، ووظائف معينة، يتم توريثها في الوقت الذي يعاني فيه الغالبية العظمى من الفقر والاحتياج والبطالة، حيث يعانون من الحرمان الاقتصادي ومن ثم يزداد نسبة الذين تحت الفقر داخل المجتمع. r- التهميش الاجتماعي: يتمثل في الفئات التي تعاني من المشكلات الاجتماعية؛ كالتفكك الأسري وارتفاع نسب الطلاق وتأخر سن الزواج وانتشار العنف اللفظي والمادي والبلطجة وارتفاع نسبة الأمية وانخفاض المستوى الثقافي لأسر بعينها، وغيرها من الأمراض الاجتماعية التي يعاني منها المجتمع. r- التهميش السياسي: الذي يأتي على قمة أنواع التهميش خاصة في الدول النامية والعربية والذي يتمنل في سيطرة جماعة أو حزب على مقاليد الحكم وتوارثه لعشرات السنين ومن ثم إقصاء واستبعاد الآخرين وعدم تقبلهم، وتمكينهم من المشاركة في الحياة السياسية.

ع- التهميش التعليمي: الذي يعد من أخطر أنواع التهميش لأنه سبب ونتيجة للأنواع الأخرى، الذي يتمنل في حرمان أبناء فئات معينة وخاصة ذوي الاحتياجات الخاصة من الالتحاق بالتعليم والاستمرار فيه نتيجة لعوامل خارجة عن إمكانيات وقدرات أبناء تللك الفئات، في الوقت الذي يتمتع فيه أبناء القلة المحظوظة اقتصاديًا أو سياسيًا أو ثقافيًا بتعليم جيد متميز مرتفع الجودة ومطابقًا للمعايير الدولية في التعليم من خلال مدارس وجامعات خاصة بمصروفات لا يقدر على تحملها معظم أبناء الطبقة

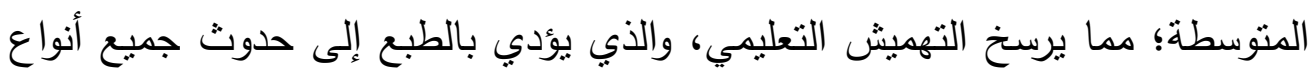
التهميش الأخرى في المجتمع المصري.

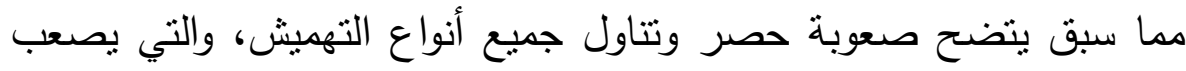

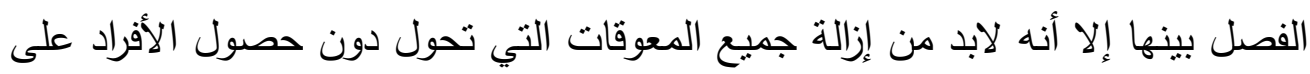
حقوقهم وفرصهم الكاملة في شتى مجالات الحياة، خاصة التعليم الذي هو أساس التماسك الاجتماعي بين أفراد المجتمع الواحد، ومن ثم تحقيق العدالة الاجتماعية والرفاهية لجميع أفراده بما ينعكس بالإيجاب على أمن المجتمع واستقراره. 


\section{ثَالثاً: التهميشيش التماليمي ومخاطره}

يعد التعليم حقًا من حقوق الإنسان في حد ذاته، وهو في الوقت نفسه وسيلة لا

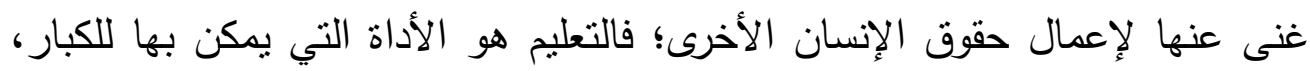
والأطفال والمهشين أن ينهضوا بأنفهر من الفقر ، وأن يحصلوا على وسيلة المشاركة الإهي كليًا في مجتمعاتهم. كما يعد التعليم حقًا شرعيًا لجميع الأطفال خاصة في المرحلة الإلزامية؛ حيث إنه من المفترض أن يساعد الأسرة في عملية التتشئة الاجتماعية السليمة للطفل

$$
\text { (فاطمة علي أبو الحديد: } 1 \text {. . rم، 9). }
$$

كما أن للتعليم دور حيوي في تمكين المرأة، وحماية الأطفال من العمل الاستغلالي، والذي ينطوي على المخاطر ، وكذا في تشجيع حقوق الإنسان والديمقراطية

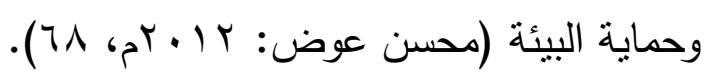

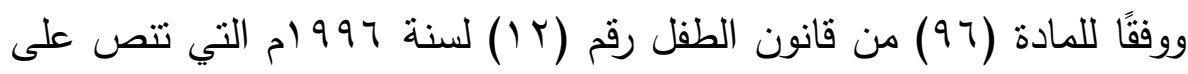

اعتبار الطفل معرضًًا للانحراف إذا اعتاد الهروب من معاهد التدريب والتعليم، كما أن

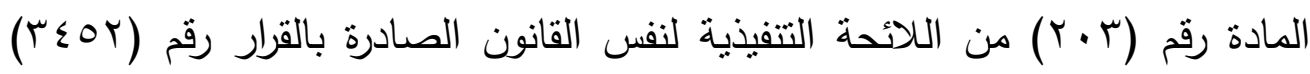
لسنة 997 ام تشير إلى اعتبار الطفل معرضًا للخطر إذا تعرض مستقبل الطفل

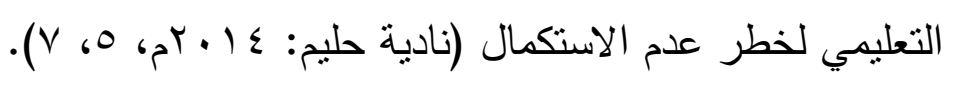

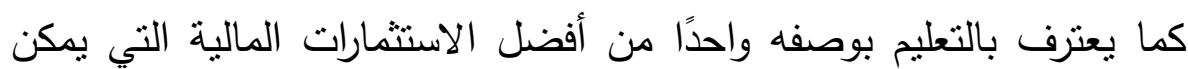

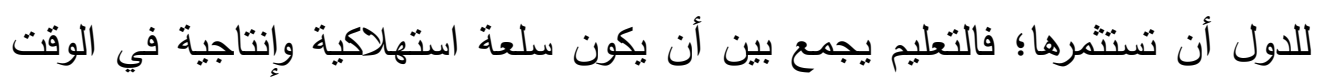

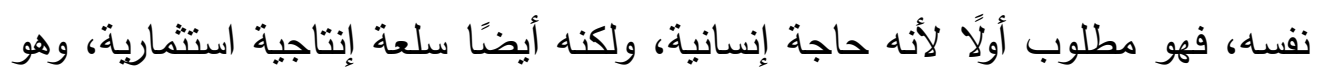
أيضًا سلعة عامة وخاصة، وأول من يفيد منه هو صاحب الثنأن، ولكنه أيضًا سلعة أنسا

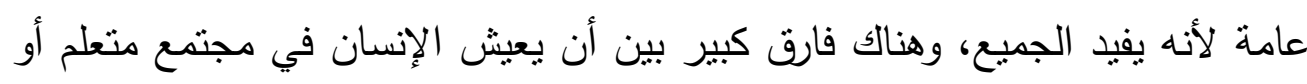

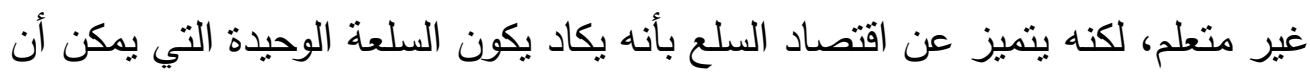

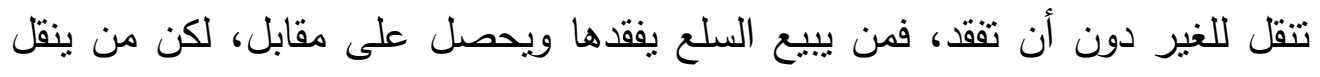
المعرفة للآخرين لا تقل معرفته بل في الغالب يتعلم من ذلك الآخر (محسن عوض: $\cdot(r) \cdot r+1) t$ 
ويعد التهميش في التعليم من أبرز المشكلات التي تواجه دول العالم النامي

ومنها مصر ؛ حيث يؤدي الفقر المتزايد في بعض الدول خاصة في المناطق الريفية إلى منع الآباء لأبنائهم من الالتحاق بالمدارس، وإدخالهم سوق العمل مبكرًا لمساعدة

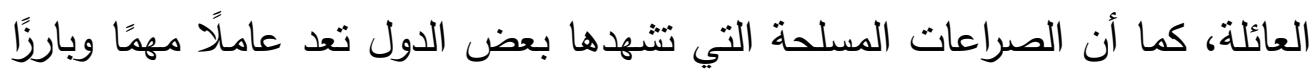
في الحيلولة دون إلحاق الأطفال بالمدارس، أو عدم تمكنهم من الحضور إلى فصولهم لهمه الدراسية بسبب انعدام الأمن، وتهدم عديد من المدارس في صراعات مسلحة (رانيا

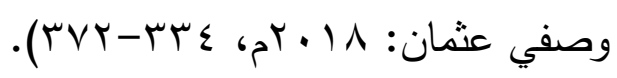

فالفقر يمتل عقبة أمام تلقي التعليم لدى rV \% من السكان، حيث إن كثير من العائلات الفقيرة ما زالت ترى أن الذهاب إلى المدرسة عملية مكلفة ماليًا، وتكون

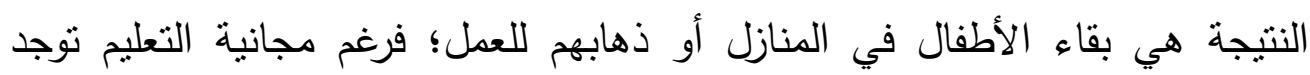

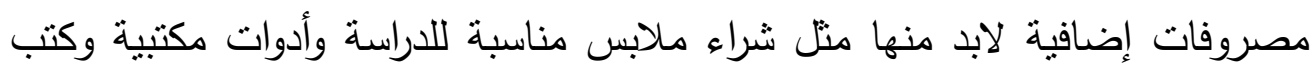
ورسوم دراسية، والمساهمة في تبرعات صيانة المدارس، وفي بعض الحالات لا توجد

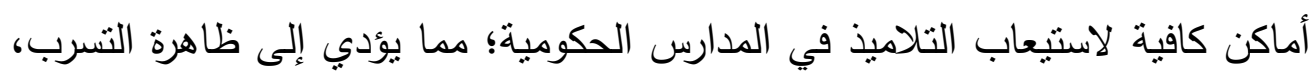
والتي تتجم عنها ظاهرة أطفال الثوارع وعمالة الأطفال (رانيا وصفي عثمان: 1 1 • rم، (rVt-rus

كما أن ظاهرة التهميش التعليمي لا تعني فقط الحرمان بمطلق العبارة؛ فهي أيضًا تعني التخلف عن بقية أفراد المجتمع؛ ففي المناطق الريفية في بعض مناطق

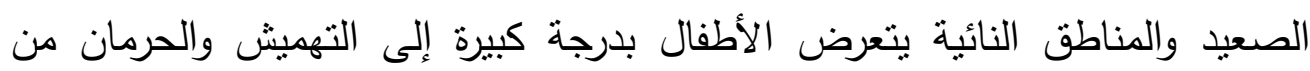
التعليم لاسيما إذا كانوا من الفقراء ومن الإناث. ويأتي الحرمان والتهميش في مجال التعليم تعبيرًا عن أوجه التقاوت كعامل إضافي في ترسيخها، وتزداد المشكلة حين تتضافر هذه الأمور مع عجز الحكومة عن توفير المدارس أو اجتذاب المعلمين من ذوي الكفاءة إلى تلك المناطق (عبدالله بيومي: (r. 
من ثم وعلى الرغم من أن التعليم حق عالمي لجميع الأطفال، فإن كثيرين منهم خارج المدارس، وتتعد الأسباب بين التقرقة الواضحة، وانعدام الخدمات في المدارس، والنتيجة هي حرمان كثير من هذه الفئات من حقهم في التعليم.

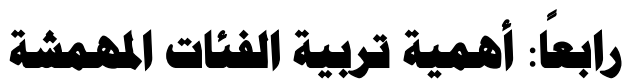

تمنتل الفئات المهيشة ثروة قومية هائلة وقوة إنتاجية عظيمة جديرة بالاهتمام، كما أن أي قصور في تربية وتعليم هذه الفئات يمثل هدرًا بشريًا وإنسانيًا بصعبه تعويضه.

وتعد تربية الفئات المهشة ضرورة اقتصادية حتى لا يكونوا عبئًا وعالة على المجتمع، كما أنها ضرورة اجتماعية حتى يتمكنوا من التواصل والتقاعل مع الآخرين، وإنسانية حتى يشعروا بوجودهم وأهميتهم بما يتقق مع التوجهات العالمية في مجال حقوق الإنسان، ومن ثم تأني أهمية تربية تلك الفئات وتأهيلها للقيام بدورها في بناء

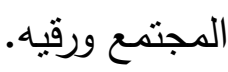

وتربية الفئات المهمشة من ذوي الحاجات الخاصة والعامة تعد مؤشرًا على سلامة المجتمع اقتصاديًا، وأمنيًا، واجتماعيًا، وأخلاقيًا؛ ومن ثم ينطلق المجتمع بيسر نحو أسباب القوة، والتقدم الحضاري (عمر مكي صغير، ميساء علي الروابدة:

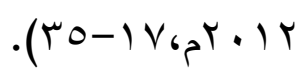

هذا بالإضافة إلى أن الوصول إلى شرائح المجتمع كافة والمناطق التي غفل

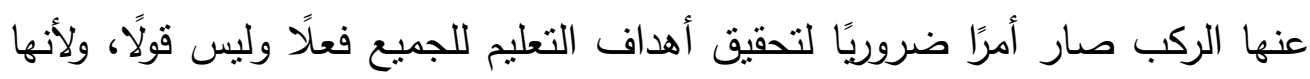

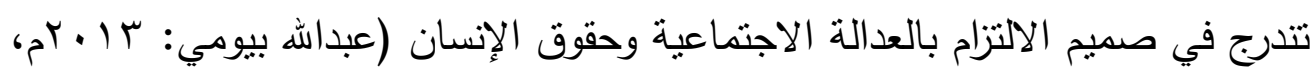
$\cdot(r \cdot r$

مما سبق يتضح أن الاهنمام بتربية الفئات المهمشة من أهم المؤشرات التي

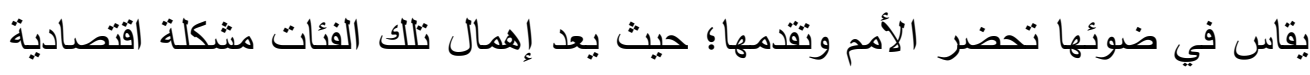

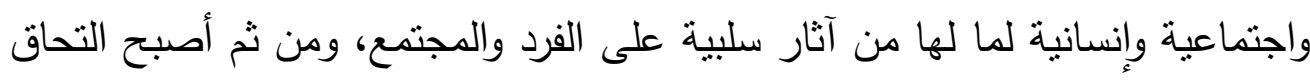
هذه الفئات بالنظام التعليمي وتمكينهم من النجاح والاستمرار فيه حقًا إنسانيًا وقانونيًا لكل فرد. 


\section{المهمر الثاني: الاتجاهات المديثة في مبال تربية الفئات المهمشة}

توجد عديد من الاتجاهات الحديثة في مجال تربية الفئات المهشة التي بدأت

كثثر من الدول تطبيقها سواء على المستوى العالمي أو الإقليمي؛ وذللك في محاولة

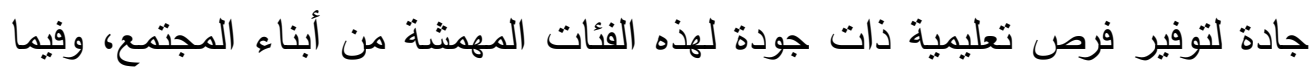
يأتي عرض لبعض من هذه الاتجاهات:

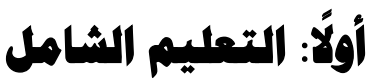

تزايد الاهنمام في السنوات الأخيرة بالتعليم الثامل من حيث المفهوم والممارسات على اعتبار أن التعليم الثامل يمثل مدخل لإصلاح العملية التعليمية في بـاتي الدول النامية والمتقدمة، واستراتيجية أساسية للتعامل مع مصادر الإقصاء والتهميش والاستبعاد.

وقد تطور مفهوم التعليم الثامل من مصطلح دمج الطلاب في المدارس دون تطوير أساليب تعليمية لهم إلى مفهوم المدرسة الخاصة والمدرسة العامة للفصل بين الطلاب العاديين والطلاب ذوي الاحتياجات الخاصة، ثم الوصول إلى التعليم الثامل أو الجامع الذي يعنى بفهم حاجات الطلاب جميعًا وتطوير الأنظمة التعليمية لتلبية احتياجاتهم.

فإذا كان الدمج أو التعليم الدامج هو توحيد لمجرى التعليم بين الطلاب

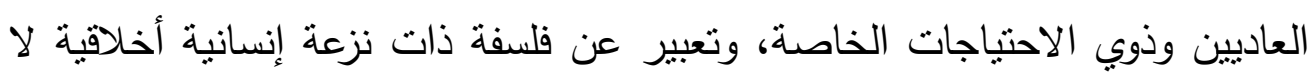
تفرق بين إنسان عادي وآخر ذي إعاقة، وإعادة صياغة لفئات المجتمع ككل، كما أنه

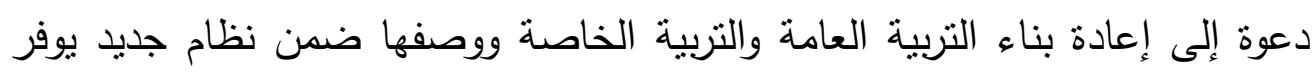
للطالب المساعدة المطلوبة في نظام الصف العادي، يأني التعليم الثامل ليكمل دور التعليم الدامج في التركيز على إحداث تغييرات في المناهج والموارد وطرق التدريس لئي

$$
\text { والمرافق (طارق محمد عبد الرحيم مهنا: } 1 \text { ( • بام، } 0 \text { ()). }
$$

كما أن التعليم الثامل عملية تدعم التنوع بين جميع المتعلمين، غايتها تحويل مهايل المدارس وسائر مراكز التعلم إلى أماكن تقدم خدماتها إلى الأطفال كافة، وكذلك سعيها

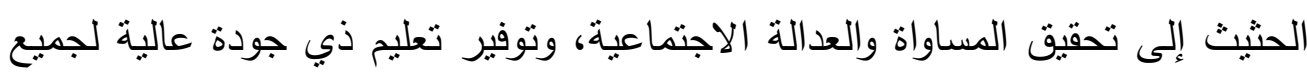


الأطفال بغض النظر عن خلفياتهم النقافية وقدراتهم العقلية وظروفهم الاقتصادية والاجتماعية والصحية والنفسية التي يعيشونها (خالد عوض مؤنس، أمجد عزت جمعة:

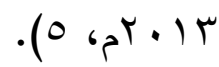

ويعرف التعليم الثامل بأنه: التعليم الذي يقبل جميع الطلاب كما هم بغض فالم النظر عن الفروق التي تتشأ نتيجة القدرات والإعاقات، ويسعى لتوفير فرص متكافئة لجميع الطلاب من خلا حصولهم على تعليم عالي الجودة (سمر أبو مرزوق،

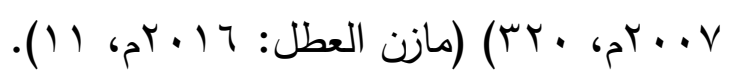
وقد أثنارت منظمة اليونسكو إلى أن التعليم الثامل هو عملية تلبي التتوع في احتياجات جميع الطلاب من خلال زيادة المشاركة في التعليم والتقافات والمجتمعات، والحد من الإقصاء من التعليم أو داخله، وهو يتطلب تغييرات في المحتوى وأساليب العمل والاستراتيجيات، والاقتتاع بأن مسئولية النظام العام أن يعلم جميع الأطفال

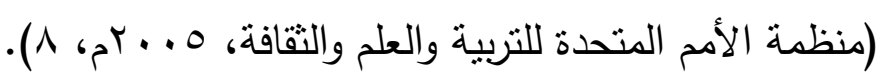
وهو عملية مستمرة تهذف إلى تقديم التعليم للجميع مع احترام التتوع والاحتباجات والقدرات المختلفة، والخصائص والتوقعات التعليمية للطلاب والمجتمعات المحلية، والقضاء على جميع أثنكال التمييز (Donnelly, Verity: 2010, 11). والتعليم الثنامل هو احتضان الجميع مع الالتزام بتوفير التعليم لكل طالب في المجتمع، وكل مواطن في دولة ديمقراطية، ويستتد على مبدأ أساسي وهو التعليم

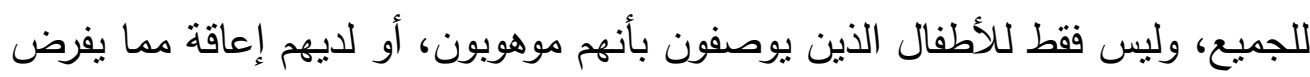
Falvey Mary a \& Givner Christine ) إعادة هيكلة المدارس وفقًا للفلسفة التالية $:(C .: 2005$ ו- كل طفل يمكن أن يتعلم وسوف ينجح.

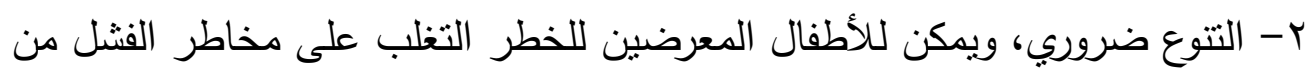
خلال المشاركة. ب- كل طفل لديه مساهمات فريدة من نوعها. ع - كل طفل له احتياجات نربوية وتعليمية. 
0- على الجميع العمل لضمان النجاح لكل طفل، مما يسهم في تحقيق نتائج تعلم فعالة.

$$
\text { في ضوء ما سبق يمكن استتناج أن: }
$$

1- التعليم الثامل يعطي الحق لجميع الطلاب في التعليم. ץ- يراعي التعليم الثامل الفروق بين الطلاب المتعلمين.

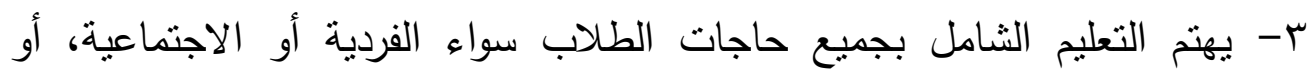
الصحية أو التعليمية. ع- يعطي التعليم الثامل فرصًا منكافئة لجميع الطلاب ويوفر بيئة خاصة لاستيعاب الفروق الفردية. ه- التعليم الثامل تعليم لجميع الأطفال معًا في نفس الفصول الدراسية، وذلك باستخدام المواد المناسبة للاحتياجات المختلفة. צ- في المدرسة الثاملة الأطفال ذوي الإعاقة لا بدرسون في فصول منفصلة، حيث يتم تصميم بيئة تضم الطلاب العاديين مع الطلاب ذوي الاحتياجات الخاصة. V- التعليم الثامل عملية مستمرة تهدف إلى تقديم التعليم للجميع مع احترام التتوع والاحتياجات المختلفة، والتوقعات التعليمية للطلاب والمجتمعات المحلية، والقضاء على لى الى جميع أشكال التمبيز ولما كانت قضية تعليم الفئات المهمشة من أكبر المشكلات التي تواجه العالم؛ فقد أثنار منتدى التعليم العالمي المنعقد في داكار عام . ... بم إلى أن التحدي الرئيس هو ضمان رؤية واسعة تتعكس على التعليم للجميع كمفهوم شامل في السياسات الحكومية الوطنية؛ فالتعليم للجميع يجب وأن يأخذ في الاعتبار الفقراء والأكثر حرمانًا، بما في ذلك الأطفال العاملين، وسكان الصحراء، والبدو الرحل في المناطق الريفية، والأقليات، والأطفال والثباب المتأثرين بالصراعات، والجوع، وسوء الحالة الصحية والذين يعانون من الاحتياجات التعليمية الخاصة ( Dakar Framework For) .Action: 2000 


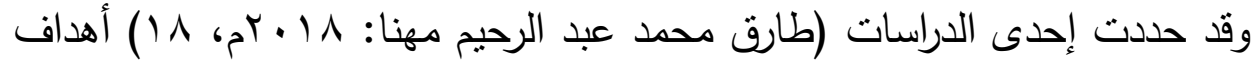
التعليم الثامل حسب الجهة المستهدفة في الآتي: 1- الجودة: الوصول إلى تعليم منتوع وعالي الجودة يحقق رغبات الطلاب وتطلعات المنظومة التعليمية. r- المنهج وطرق التدريس: التركيز على التعلم النشط وتحسين جوانب التعلم. r- المعلمون: تفعيل دورهم وإكسابهم المهارات النظرية والعملية للتعليم الثامل. ع - الطلاب: استيعاب وتعليم وإشرالك جميع الطلاب وتلبية احتياجاتهم.

0- الدعم المقدم: توفير الدعم المناسب لجميع الطلاب حسب الاحتباجات الفردية. ومن ثم تركز أهداف التعليم الثامل على تقديم تعليم ذي جودة لجميع الطلاب، الأمر الذي يستلزم تطوير المناهج، تدريب المعلمين، مع مراعاة برامج الدعم والمساندة الفردية. وقد أوضحت اليونيسيف (اليونيسيف: ؟1 ـ rم، ؟) مبررات تطبيق التعليم الثنامل

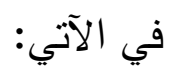
1- مبرر تعليمي؛ حيث إن مطالبة المدارس باستيعاب جميع الأطفال بعني أنه بتعين عليها استحداث وتطوير أساليب وطرق تدريس واستراتيجيات تعليمية حافزة للتعليم والتعلم، وتنتجيب للاختلافات بين الأفراد ويستقبد منها جميع الطلاب على اختلاف قدراتهم وإمكانياتهم. ץ- مبرر اجتماعي؛ حيث إن المدارس الثاملة قادرة على تغيير المواقف والاتجاهات السلبية نحو النتوع عن طريق تعليم جميع الأطفال معًا، ومن ثم وضع الأسس لبناء مجتمع عادل يستوعب شرائح المجتمع كافة غير قائم على التمبيز والتهميش لفئات المجنمع. r- مبرر اقتصادي؛ حيث إن إنثاء وصيانة مدارس تقدم التعليم لجميع الأطفال يعتبر أقل تكلفة من إقامة شبكة معقدة من المدارس تختص بمجموعات مختلفة من الأطفال.

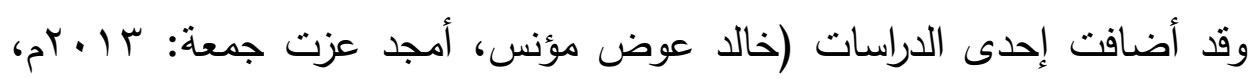
T) مبررًا دينيًا يقره الدين الإسلامي؛ حيث أقام الإسلام المجتمع على دعائم قوية ثابتة 
منها: العدل بين الناس على اختلاف أجناسهم وطبقاتهم، والمساواة وتكافؤ الفرص التعليمية بين الناس، كما أنه يقر بالتفاوت بين الناس كل حسب قدراته وطاقاته الخاصة التي يجب أخذها في الاعتبار في العملية التعليمية. من هذه المبررات السابقة يتضح أنها ركزت على العدل والمساواة في تحقيق التعليم

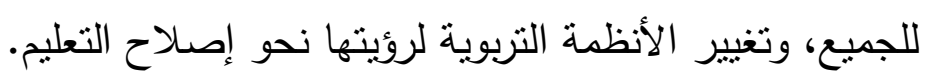

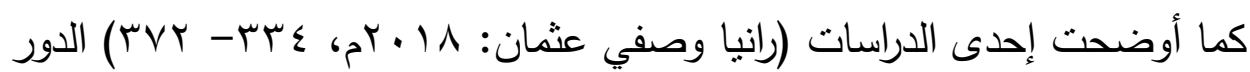
الذي يمكن أن يقوم به التعليم الثامل في تربية الفئات المهشة حيث إنهابـ إنها: 1 - يعد صيغة من صيغ التعليم الفعالة للتغلب على التهميش في التعليم. r- جاء استجابة للأهداف التي نم اعتمادها في المنتدى العالمي للتعليم في داكار التي أكدت على مفهوم التعليم للجميع. r- يستتد على الحق في تعليم جيد للجميع يلبي احتياجات التعليم الأساسية، ويثري حياة الدارسين.

ع- يركز بوجه خاص على الفئات المهشةة، ويرمي إلى تمكين الجميع من تتمية

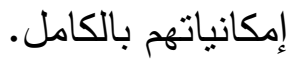
0- يحترم التتوع والاحتياجات المختلفة، والخصائص والتوقعات التعليمية للطلاب والمجتمعات المحلية. 7- بياعد في القضاء على جميع أشنكال التمييز داخل المجتمعات. - يرتبط بمبدأ تكافؤ الفرص، ومبدأ التتوع لمقابلة احتياجات جميع الفئات، ومبدأ الحق في التعليم. - الحن. ᄉ- يسهم في تلبية الاحتياجات التربوية والتتموية لجميع الفئات المهشة. وعلى ذلك إذا كان التعليم الثامل أحد الاتجاهات الحديثة في تربية الفئات

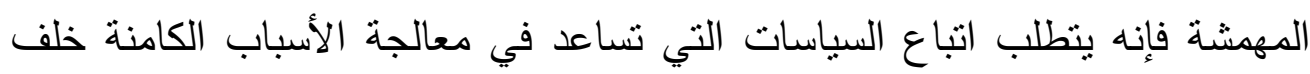
التهميش مثل: عدم المساواة، والفوارق بين الجنسين، والعيوب العرقية، واللغوية، والفوارق بين المناطق الجغرافية مع التزام سياسي مستمر بالعدالة الاجتماعية، بالإضافة

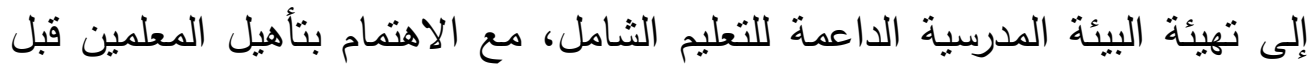


الخدمة وأثنائها، وذللك في ضوء فلسفة التعليم الثامل، وكذلك التعاون الفعال بين الحكومات والهيئات والوزارات، وضمان الثراكة الفعالة مع منظمات المجتمع المختلفة. ثانياً: توظيف المستمدثات التكنملومجية في تربية الفئات المهمشية

تعد المستحدثات التكنولوجية فرصة ذهبية لاحتواء الفئات المهيشة ورعايتها وإدماجها ضمن نسيج المجتمع، وتحويلها لعناصر منتجة وفعالة؛ لذا جاءت استراتيجية الاستفادة من التقانات الحديثة للمعلومات والاتصال من الاستراتيجيات المهمة التي اقترحها مؤتمر داكار لتحقيق أهداف التعليم للجميع. ففي مجال تربية الفئات المهمشة من ذوي الإعاقة تم الاتجاه نحو إنتاج برامج تعليمية لهذه الفئات من قبل عديد من الباحثين، ومن قبل الجهات المسئولة كما هو الحال في مجهودات مركز التطوير التكنولوجي الذي أعد بالفعل إسطوانة واحدة بها

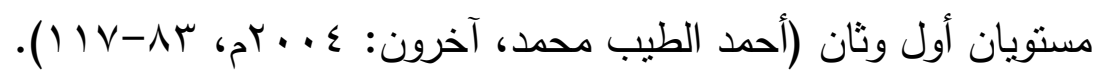
هذا بالإضافة إلى اختراع كثير من الأجهزة التي تعوض القصور في بعض احض إندان الحواس لديهم وكذلك الاستفادة من المستحدثات التكنولوجية في إعداد الوسائل التعليمية الحديثة المستخدمة في عمليتي التعليم والتعلم.

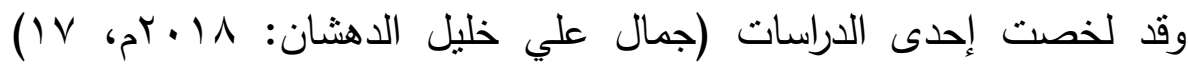
أهمية استخدام المستحدثات التكنولوجية في تعليم ذوي الاحتياجات الخاصة على النحو الآتي: 1- معالجة الفروق الفردية التي تظهر بوضوح بين المعاقين بمختلف فئاتهم، مما يجعل إخضاعهم جميعًا لطريقة تعليمية واحدة غير مجدية. r- تعليم المعاقين الأنماط السلوكية المرغوب فيها، وإكسابهم المفاهيم المعقدة. ץ- التغلب على الانخفاض في القدرة على التفكير المجرد للمعاقين، وذلك بتوفير خبرات حسية مناسبة. ع- نشويق الطلاب المعاقين، وزيادة دافعيتهم للتعلم؛ حيث نركز على التعزيز والتغذية الراجعة. 
0- تكرار الخبرات، وتجعل الاحتكاك بين الطفل المعاق وبين ما بتعلمه احتكاكًا مباشرًا، والذي يعد مطلبًا تربويًا تفرضه طبيعة الإعاقة. 7- زيادة التحصيل وتكوين اتجاهات إيجابية للأطفال المعاقين. V- إكساب الأطفال المعاقين المهارات الأكاديمية اللازمة لتكيفهم مع المجتمع المحيط

وفي مجال نربية الفئات المهمشة من الموهوبين والمتفوقين فإنه نوجد ركائز

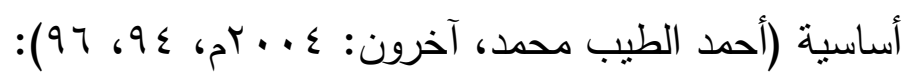

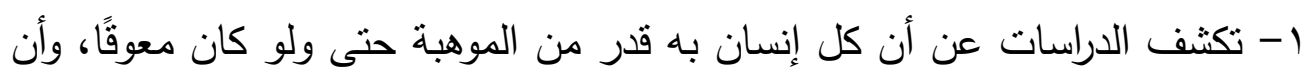
هذه الموهبة ديناميكية ذات مجالات مختلفة، أو مستويات متدرجة ومنتوعة، فردية أو جماعية وهي مفهوم مجرد يستذل عليه من أداء الطلاب وعلى مدى زمني في مواقف متتوعة؛ مما يتطلب تجديد نواتج التعلم للطلاب الموهوبين، والتي تختلف عن تلك المتوقعة من زملائهم العاديين. r- نظرية الذكاءات المتعددة " لجاردنر" تؤكد أن كل طالب لديه نصيب من الذكاءات، يمكن تتميتها والارتقاء بها إلى مستوى مناسب، وتوجيه خبرات التعليم والتعلم. ب- تنمية الموهبة العلمية والتكنولوجية لدى الطلاب ينبغي أن تنال اهنمامًا فائقًا من المؤسسات التعليمية والمجتمعية، بحيث تكون نواه لإنشاء قاعدة علمية تكنولوجية، ومجتمع تعلم يعتمد على العلم والتكنولوجيا. ع- الطلاب الموهوبون لديهم القدرة التي تمكن من استخدام استراتيجيات تعليم وتعلم متتوعة معهم، ومنها: تعليم التفكير الذي ينمي القدرة على الانتقاء، والتفكير النقدي

$$
\text { والإبداعي، والمهارات الأساسية. }
$$

وفي ضوء ذللك يحتاج الطلاب الموهوبون إلى وسائط تعليمية متقدمة، تمكن كل منهم من أن يتعلم ذاتيًا وحسب استعداده، وبما يتفق مع ميوله ورغباته. ولذلك فإن استخدام التكنولوجيا المتقدمة، ومصادر المعرفة المتعددة بساعد هذه الفئات المهمشة من الموهوبين لإتقان استخدام الحاسبات وتطبيقاتها، وبرامجها بفاعلية، وأن يتعرفوا على مصادر المعرفة المتعددة، والتكنولوجيا المتقدمة ويوظفوها بفاعلية مما 
يؤدي إلى محو الأمية المعلوماتية، وبالتالي إلى تتمية التفكير الناقد، وحل المشكلات، واتخاذ القرارات المناسبة.

وفي مجال محو الأمية وتعليم الكبار تؤدي المستحدثات التكنولوجية دورًا كبيرًا في تجاوز هذه المشكلة والقضاء عليها؛ حيث تم تطوير المصادر المطبوعة ومواد التعليم الجمعي، التي أصبحت نتكل حافزًا كبيرًا للمتعلم للاستمرار في التعليم وتحقيق النتائج الإيجابية.

وهو ما أشثارت إليه تقارير الدول العربية في سبيل القضاء على الأمية في هذه الدول وبصفة خاصة في نوظيف برامج الفيديو والتليفزيون التعليمي في المشاركة

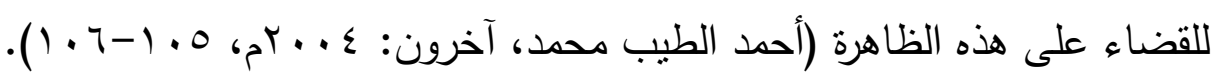
هذا بالإضافة إلى أن هذه المستحدثات يمكن أن تساعد على زيادة سبل التعليم، وتحسين نوعيته؛ إذ تتيح هذه الوسائل الوصول إلى أولئك الذين يتعذر الوصول إليهم، بالإضافة إلى تحسين رصد التقام المحرز في مجال محو الأمية وتعليم الكبار . وعلى ضوء ذللك الاتجاه نحو توظيف المستحدثات التكنولوجية في تربية الفئات المهشة يمكن جذب كثير منها للمؤسسات التعليمية، والاحتفاظ بالبعض الآخر داخلها، كذلك تربية بعض الفئات المهيشة من المعاقين والموهوبين، كما يمكن الحد من مشكلة الأمية والتسرب من التعليم التي تعد الأساس الحقبقي وراء كثير من الظواهر كأطفال الثوارع وعمالة الأطفال، والمنحرفين منهم خاصة. إلا أنه على الرغم من التقدم الملحوظ في توظيف المستحدثات التكنولوجية في تعليم الفئات المهيثة، وكذلك السعي لدمج التكنولوجيا في العملية التعليمية، يظل كثير لترب من هذه الفئات قد لا تجد هذا الدعم الذي تجده فئات ذوي الاحتياجات الخاصة منل: الفئات الفقيرة التي لا تتعامل مع هذه المستحدثات أو حتى تقترب منها. هذا بجانب أن كثير من المؤسسات التعليمية في المناطق الفقيرة وليست العشوائية فقط، تفتقد إلى البنية الأساسية، والتجهيزات الخاصة بالتعامل مع هذه المستحدثات وتوظيفها، كذلك قلة الوعي بأهمية المستحدثات التكنولوجية في هذا

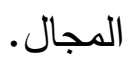




\section{ثالثاً: استفدام الخريطة التعليمية كأمد أساليب التفطيط التربوي في \\ توفير الفرص التعليمية لبعض الفئات المهمشة}

نتيجة لزيادة وعي معظم الدول بأهمية التخطيط التربوي في تحقيق التتمية

الثاملة واهتمام بعض المنظمات الدولية والمحلية؛ كالمعهد الدولي للتخطبط والمكتب الإقليمي لليونسكو في الدول العربية بالإشراف والمساهمة في إعداد عديد من الخرائط المدرسية، والتعليمية في عديد من الدول "لأن التردد في استخدام الخريطة المدرسية في العمل التخطيطي قد يؤدي إلى سوء توزيع الإمكانات التعليمية، وقد ينجم عنه عدم تحقيق مبدأ نكافؤ الفرص التعليمية، فضلًا عن وجود فجوة زمنية بين ظهور الحاجات التربوية وإمكانات تلبيتها؛ ومن ثم كان وجود الخريطة المدرسية ضمان يمنع التوسع أو التوزيع غير العقلاني للمباني المدرسية" (محمد سيف الدين فهمي: . . . بام، 1 ( ). والخربطة التعليمية هي رسم وتجسيد لروئية مستقلية للمؤسسات التعليمية على مستوى الإدارات التعليمية بالمديريات المختلفة في ضوء الظروف والإمكانات المتوقعة، وهي تختلف عن الخريطة المدرسية التي هي رسم وتجسيد لروية مستقبلية للمؤسسات التعليمية النظامية في مراحل التعليم قبل الجامعي في منطقة جغرافية محددة وفي ضوء الظروف والإمكانات المتاحة والمتوقعة، أما عن الخريطة التربوية فهي رسم وتجسيد لروئة مستقلية للمؤسسات التعليمية النظامية وغير النظامية في منطقة جغرافية محددة، وفي ضوء الظروف والإمكانات المتاحة والمتوقعة، ومن ثم فهي أكثر ارتباطًا بحياة الإنسان وأكثر مرونة ونتوعًا، وأعم واشمل من الخريطة المدرسية التي تعد صورة مصغرة وجزء منها، بينما تأتي الخريطة التعليمية كمرحلة وسط بين الإثثين وحلقة وصل بينهما (هانم خالد محمد محمد سالم: 11 ( بم، 97).

وتهدف الخريطة التعليمية بشكل عام إلى تحقيق مجموعة أهداف من أهمها: تحقيق تكافؤ الفرص التعليمية أمام جميع المتعلمين؛ من خلال توزيع الخدمات توزيعًا

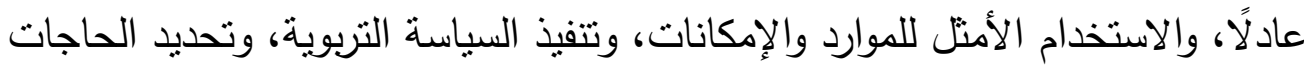
من الأبنية المدرسية، واختيار أماكنها ووضع أولويات تتفيذها (منير عبد الله حربي:

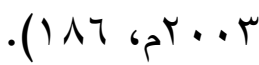


وقد لخصت إحدى الدراسات أهداف الخريطة التعليمية في عدة أهداف عامة وتتخيصية وتتبؤية، يتم من خلالها رصد الواقع التعليمي داخل المدارس والإدارات التعليمية المختلفة، وفي ضوء التشخيص يتم وضع رؤى مستقبلية ببدائل متعددة، يتم من خلالها اختيار البديل الأمتل في ضوء الظروف والإمكانات المتوقعة والمرتبطة بآليات تحويل البديل لواقع عملي مجسد، يتمثل في إناحة فرص نربوية عادلة لجميع

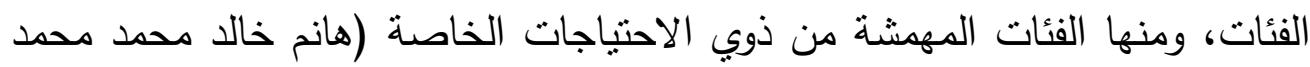

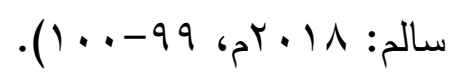

ومن ثم تعد الخربطة التعليمية أحد أساليب التخطيط التربوي القديمة والحديثة والتي تختلف باختلاف المنطقة أو النظام التعليمي، أو المرحلة التعليمية أو الفئة

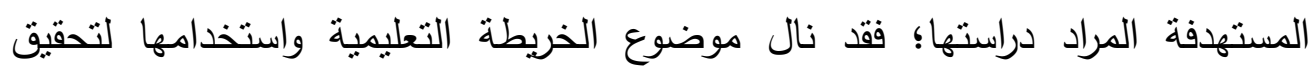
العدالة التربوية اهتمام عديد من الباحثين في مجال أصول التربية والتخطيط التربوي منذ زمن بعيد لما له من أهمية في وضع رؤية مستقبلية للفرص التعليمية وإتاحتها على الى كافة المستويات.

وقد نالت الفئات المهمشة بعض من هذا الاهتمام؛ حيث جاءت إحدى

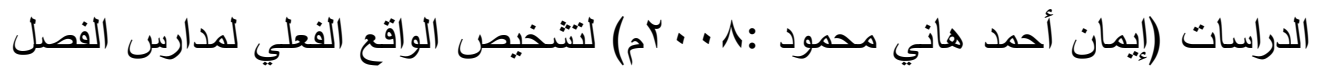

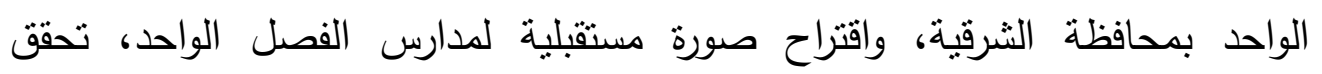
الاستيعاب الكامل وتحقيق العدالة التربوية.

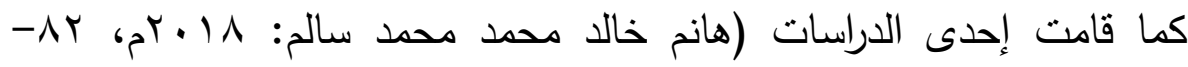
rM (1) بالكثف عن واقع الفرص التعليمية المتاحة لبعض الفئات المهيشة من ذوي الاحتياجات الخاصة بمراحل التعليم قبل الجامعي بمحافظة الثرقية، ووضع خريطة تعليمية لتوفير فرص تعليمية جادة وحقيقية لتلك الفئات. وعلى ضوء ذلك يمكن أن يكون أسلوب التخطيط التربوي باستخدام الخرائط

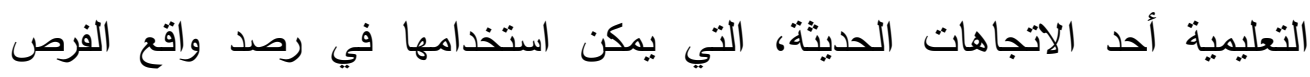
التعليمية المتاحة لبعض الفئات المهشة من الأميين، وذوي الإعاقة، والموهوبين، وأطفال المناطق العشوائية، والأطفال من سكان المقابر، وغيرها من الفئات المهشئة الإعنة ودئه 
والمحرومة من التعليم، على مستوى القرى والمراكز والمحافظات، والذي في ضوئه يتم استشراف المستقبل، ووضع الرؤى المستقبلية لتوفير فرص التربية لهذه الفئات، وفي ضوء الظروف والإمكانات المتاحة والمتوقعة لكل منطقة.

\section{رابهاً: مشاركة منظمات المتمع المدني في تربية الفئات المهمشة}

يثير الواقع الحالي لعدم كفاية الجهد الحكومي في مكافحة الفقر وصور التهميش المختلفة التي يعاني منها الواقع المصري؛ لذلك فإن الجهد غير الحكومي الذي يمكن أن تضطلع به مؤسسات المجتمع المدني قد أصبح ضرورة لا غنى عنها، وإذا كانت هذه الحقيقة واضحة في كل المجالات فإنها أكثر وضوحًا في مجال التعليم بصفة عامة وتعليم الفئات المهمشة خاصة؛ لذلك يوجد اتجاه قوي نحو دعم جهود مؤسسات المجتمع المدني، والاستفادة منها في مجال تعليم الفئات المهمشة. ويقصد بمنظمات المجتمع المدني: مجموعة من المؤسسات والجمعيات والاتحادات غير الحكومية وغير الرسمية، التي ينضم إليها الأفراد بشكل اختياري

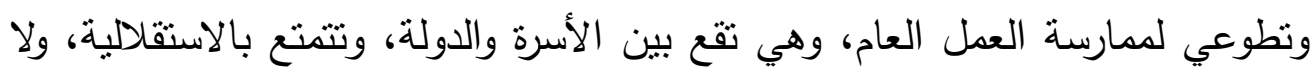
تسعى إلى الربح، وتهدف إلى تحقيق النفع العام للمجتمع (إبراهيم محمد إبراهيم:

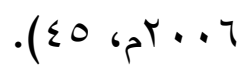

ويعد السعي إلى تمكين الفئات المهشة في المجتمع، من خلال تقديم برامج التعليم والتعلم المناسبة طبقًا لحاجاتهم وأدوارهم الاجتماعية، من أهم الأدوار التي يمكن لهن

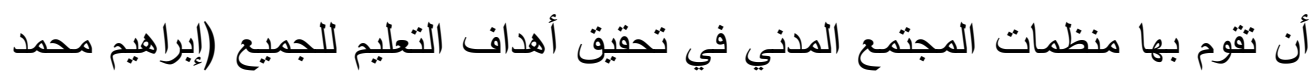

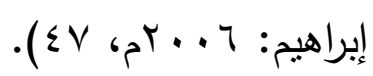

كما ينظر إلى هذه المنظمات باعتبارها الأساس لتشكيل مستقبل الحركة التتموية في العالم، والآلية الفعالة لتعظيم عوائد تتفيذ المبادرات الإصداحية، ولتقليل Hutter, Bridget\& O Mahony, ) معاناة الفئات الضعيفة والمهشة في المجتمع .(Joan:2004,12 وبعني هذا أن تساعد هذه المنظمات الثرائح المهيشة، ويتحقق ذلك من خلال نظرة المنظمات النظوعية إلى المحرومين والفقراء باعتبارهم مواطنين لهم نفس الحقوق، 
وعليهم نفس الواجبات، ويجب أن تتصف مبادرات هذه المنظمات بدمج كافة شرائح المجتمع دون استثناء أو إقصاء (Pospisilova, Tereza: 2002, 26). وتزداد أهمية هذه المنظمات في ظل تمتعها بعدد من المزايا النسبية، ومن بين هذه المزايا: انخفاض تكلفة تتفيذ مبادراتها التتموية، وقدرتها الضخمة على حشد وتعبئة أعداد كبيرة من المتطوعين والذين يعملون بدون أجر، أو بأجور منخفضة، وقدرتها وفيا على العمل في ظل الضغوط المالية، وتبنيها فلسفة تتموية تقوم على التعليم من خبرات

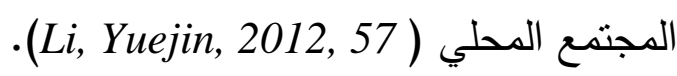
لذا كانت استراتيجية تأمين التزام المجتمع المدني ومشاركته في صياغة استراتيجيات تطوير التعليم وفي تتفيذها ومتابعتها، من أهم الاستراتيجيات التي اقترحها مؤتمر داكار لتحقيق أهداف التعليم للجميع. وتعد الجمعيات الأهلية أحد مؤسسات المجتمع المدني التي تزايد الاهتمام

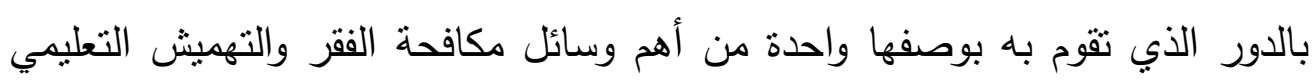
والاجتماعي والصحي، خاصة في الدول الفقيرة، واستتادًا إلى نشأتها الثعبية وفلسفتها وامتدادها الواسع في مختلف المجالات وقيامها بتنظيم برامج التدريب والتوعية والتعليم والتوجيه الصحي للفئات المهشة من الفتيات، وبناء قدراتهن من خلد نتمية مهاراتهن للوصول للخدمات الصحية والتعليمية والاقتصادية، وتدريبهن على بعض المشروعات الصغيرة، التي يمكن أن توفر لهن عائدًا، وكذلك الاهتمام بمشروعات محو الأمية

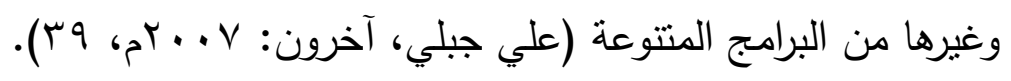

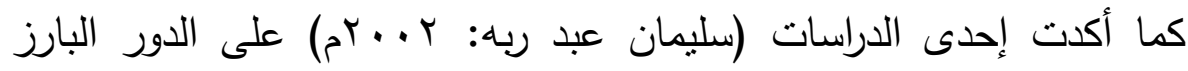
الذي تقوم به الجمعيات الأهلية في دعم العملية التعليمية؛ وذلك من خلال الجهود التي تقدمها هذه الجمعيات في توفير فرص تعليمية بديلة للفئات المهمشة من الأطفال في

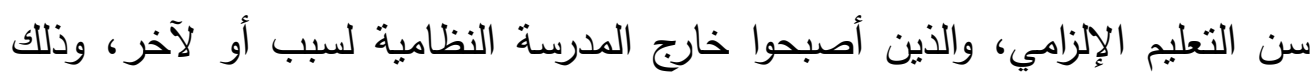
بالمساهمة في إنثاء مؤسسات التعليم الموازي كمدارس المجتمع ومدارس الفصل الواحد

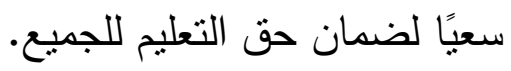


وهي مؤسسات توفر تعليمًا نوعيًا للفئات المهمشة من الأطفال - خاصة الفتيات في سن التعليم الابتدائي- واللاتي تم تهميشهن وإقصاءهن عن التعليم النظامي؛

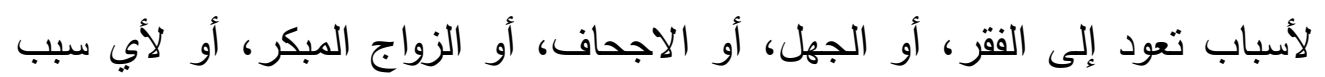

وفي مجال تربية الفئات المهمشة من الفتيات توصلت نتائج إحدى الدراسات

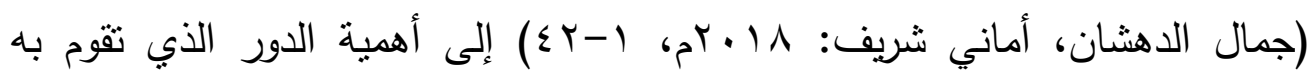

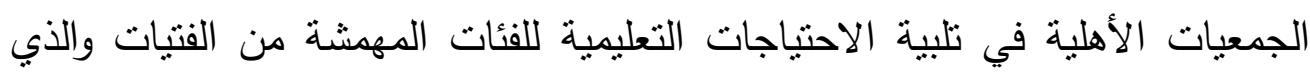

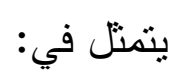
1- إسهام الجمعيات الأهلية بدور كبير في الحد من التهميش التعليمي للفتيات في المناطق المحرومة من التعليم في القرى والنجوع بمحافظات الجمهورية. ץ- تركيز نشاط هذه الجمعيات في مجال التعليم في صعيد مصر لكونه أكثر الأقاليم التي تعاني من الفقر والحرمان من التعليم.

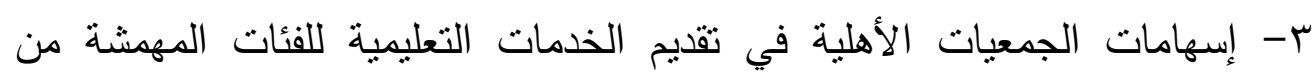
الفتيات يتمثل في: إنشاء المدارس وتجهيزها وصيانتها، توفير الموارد المالية والمادية اللازمة لها، تدريب المعلمين والإداريين بمدارس الفتيات. من ثم تعد مشاركة جهود المجتمع المدني أحد الاتجاهات التي يمكن عن طريقها تقديم الخدمات التعليمية للفئات المهمشة والمحرومة من التعليم، الأمر الذي لهي

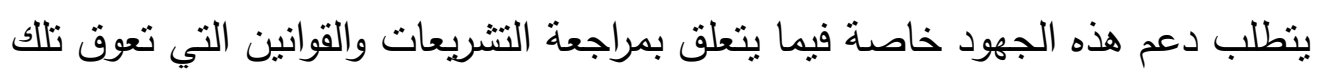
الجهود، وتوفير المعلومات والبيانات المتاحة عن تللك الفئات، بالإضافة إلى التسيق لهنيق والتكامل بين هذه الجهود، وكذلك توسيع أنشطة الجمعيات الأهلية لنتمل الأطفال ذوي

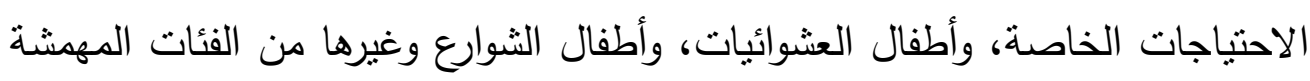
في الأحياء الفقيرة والمناطق الريفية النائية.

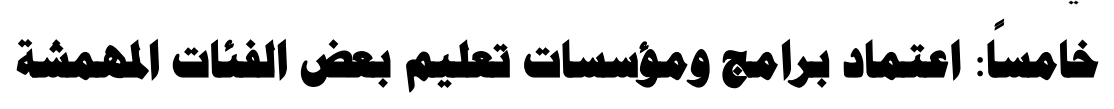


تزايد الاهتمام في العقدين الأخيرين من القرن العشرين بجودة التربية، ومن المتوقع أن يزيد هذا الاهتمام في المستقبل خاصة في ظل التنني المستمر في الأداء التعليمي في الدول العربية. ولما كانت "العبرة ليست في وجود برامج ومؤسسات وإدارة وميزانيات بقدر ما

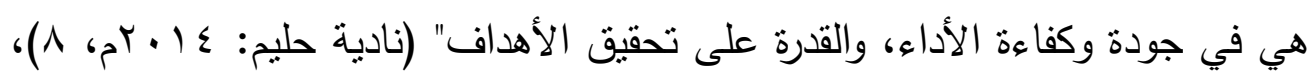
وانطلاقًا من الاهتمام العالمي بتحسين جودة التعليم من جهة، والتركيز على الفئات المهيشة في النظام التعليمي من الفقراء الذين تم إقصاءهم لسنوات طويلة، قامت الهيئة القومية لضمان جودة التعليم والاعتماد وبالتعاون مع وزارة التربية والتعليم ومنظمة الأمم المتحدة للطفولة "اليونيسف" بإعداد وثثقة معايير ضمان جودة واعتماد لمؤسسات (مدارس) التعليم المجتمعي تتكون من عدة معايير هي: بيئة التعلم، المشاركة المجتمعية، المتعلم، المعلمة، التتمية المهنية المستدامة؛ لتكون حجر الزاوية في تأهيل هذه المؤسسات للاعتماد وتحسين جودة الفاعلية التعليمية بها، بما ينعكس على تتمية قدرات ومهارات الفئات المهشة من الفتيات المحرومات من التعليم، اللاتي لم تتح لهن فرصة الالتحاق بالتعليم النظامي. ويتمنل الهدف العام من إعداد معابير جودة واعتماد مؤسسات التعليم المجتمي في جمع الجهود المبذولة في مجال التعليم بمشاركة منظمة الأمم المتحدة للطفولة "اليونيسف"، ومؤسسات المجتمع المدني المختلفة، منذ التسعينيات من القرن الماضي في إطار موحد يسمح بإحداث نقلة نوعية في مدخلات ومنظومات العمل في هذه النوعية من المؤسسات بما يضمن جودة أدائها وتحقيق نواتج التعليم المستهدفة للفئات المهمشة من الأطفال المتسربين من التعليم ودمجهم في التعليم النظامي (الهيئة

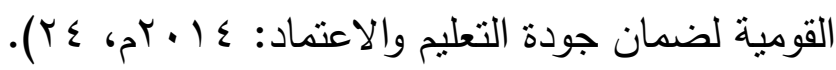
وينبثق من هذا الهدف العام عدة أهداف إجرائية من أهمها (الهيئة القومية

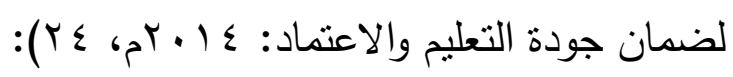

1- استكمال منظومة إعداد معايير ضمان جودة واعتماد جميع مؤسسات التعليم قبل الجامعي. 
r- تحسين جودة أداء مؤسسات وفصول التعليم المجتمي بكافة أنماطها. r- مراجعة وتقويم أداء مؤسسات التعليم المجتمي، وتحديد نقاط القوة والضعف طبقًا لكعايير ضمان الجودة والاعتماد ومؤشراتها. ع- تحديد مستوى المؤسسة التعليمية وقدرتها على تقديم الخدمة التعليمية للفئات المهمشة من المتسربين أو غير الملتحقين بالتعليم النظامي مقارنة برسالتها المعلنة. كما قامت الهيئة بتقديم تدريبات للمعلمين والمعلمات بهذا النوع من التعليم على بلى بهي تطبيق معايير الجودة بهذه المؤسسات وتأهيلها للاعتماد من قبل الهيئة. هذا بالإضافة إلى إطلاق وتششين نظام معلومات متكامل لمنظومة جودة التعليم المجتمي تربط جميع الجهات ذات الصلة بدءًا بالمدرسة المجتمعية والإدارة والمديرية التعليمية التابع لها ونهاية بالموقع الإلكتروني للهيئة، ويتضمن هذا النظام قاعدة بيانات مصغرة تعمل على جهاز الحاسب الآلي الخاص بالمدرسة المجتمعية، بما يسمح للمدرسة بالقيام بإعداد دراسة ذاتية إلكترونية خاصة بها لقياس مدى بهى استعدادها للتقدم للاعتماد، بالإضافة إلى وجود قاعدة بيانات تجميعية على مستوى بإنى الإدارات والمديريات التعليمية بمختلف المحافظات، تقوم بتجميع البيانات من المدارس المجتمعية على الموقع الإلكتروني الخاص بها، على أن يتم وضع الصلاحيات على لإنى الموقع الإلكتروني للجهات المسئولة للاطلاع على البيانات واستخراج الإحصاءات، والوقوف على نقاط الضعف ووضع خطط التحسين لعلاجها (رئيس الهيئة القومية لضمان جودة التعليم والاعتماد: 0 1 • بم). كما تتطلع الهيئة من خلال مجهوداتها أن تحقق مجموعة أهداف مستقبلية لمدارس التعليم المجتمعي منها (الهيئة القومية لضمان جودة التعليم والاعتماد:

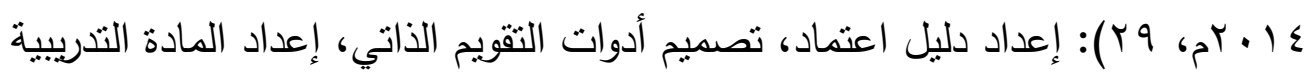

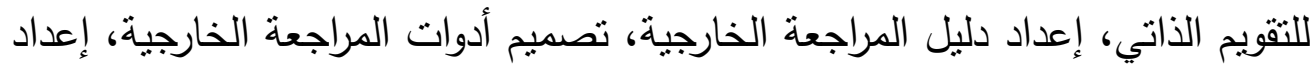
المادة التدريبية للمراجعة الخارجية، إعداد دليل الممارسات المتميزة، تدريب الموجهين والمشرفين على كيفية تحقيق معايير الجودة والاعتماد، تدريب القائمين بالدراسة الذاتية، إعهاء تدريب المراجعين الخارجيين على آليات المراجعة الخارجية. 
وعلى ضوء ذلك الاتجاه فإنه من حق هذه المؤسسات أن تتقدم للاعتماد، ويتم مراجعتها وزيارتها ومساعدتها في وضع خطة تحسين، وتحديد نقاط القوة والضعف بأدائها وإعطاء من يستحق منها شهادة اعتماد من الهيئة القومية لضمان جودة ولهان التعليم والاعتماد عند استيفاء المعايير المعترف بهاء. هذا بالإضافة إلى أن هذا الاتجاه يستهذف الارتقاء بمخرجات التعليم المجتمي، ويمكن الفئات المهشمة من الأطفال من الحصول على فرصة نعليم جيدة وذات جودة عالية، وهذا بدوره سوف يساعد على الاحتفاظ بهذه الفئات داخل مؤسسات

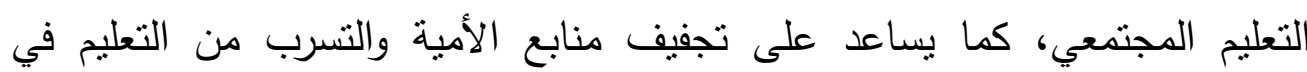
المناطق المحرومة.

وفي مجال نربية الفئات المهمشة من ذوي الإعاقة وتطور فلسفة الدمج في مدارس التعليم العام وتزايد المؤيدين لها في الوسط التربوي، فقد تأسست عدة هيئات في الدول المتقدمة لاعتماد برامج التربية الخاصة، ومنها الهيئة الوطنية لاعتماد خدمات التعليم الخاص في الولايات المتحدة الأمريكية؛ حيث تقوم هذه الهيئة بتقييم برامج التربية الخاصة تقييمًا فعالًا وبناء على معايير الجودة (The National Commission) :2009,3) for the Accreditation of Special Education Services وللعمل على تحقيق الاعتماد الأكاديمي لبرامج التربية الخاصة وضعت مجموعة من المنظمات والهيئات التربوية معايير معتمدة للتربية الخاصة، بعضها مستقل تمامًا عن التعليم العام، والبعض الآخر ضمن معايير التعليم العام. من أثهر هذه المعايير: معايير جودة التعليم الثامل- لإنهاء العزل: ، Inclusive quality education-to end exclusion وتتضمن تسعة معايير، ويتبع كل معيار عدد من المؤشرات هي: المعلمون Teachers

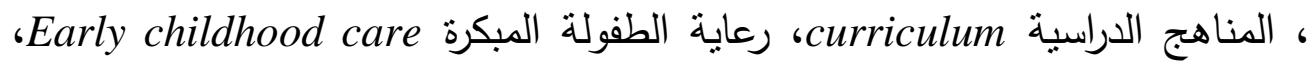
اللغة Language، بيئة تعليمية شاملة Inclusive Learning Environment، مدارس صحية Healthy Schools، المواد التعليمية Learning material، تقييم الطلاب ‘(Unesco: 2010) Learning styles أنماط التعلم، Assessment of students 
Disability's Standards for Education والمعايير التربوية للإعاقة بأستراليا وتغطي المعايير المجالات التالية: معايير الالتحاق Standards for enrolment؛ معايير المشاركة standards for participation، معايير تطوير المناهج الدراسية standards for curriculum development standards for student support services standards harassment and victimisation ولكل معيار من هذه المعايير عدد Disability standards for Education In Asturalia: 2005, من مؤشرات الأداء .(14-18)

standards for توجد أيضًا معايير التربية الخاصة بولاية ألبرتا في كندا special Education in Alberta ألبرتا في دولة كندا عام ع .. r للصفوف من (1-r (1)؛ وذلك بهدف إيجاد برنامج تعليمي ذي جودة عالية يلبي احتياجات جميع المتعلمين من ذوي الإعاقة، وتتوزع هذه المعايير في أربعة مجالات وهي: الوصول Access ، التقييم Assessment، الملاعمة standards for special ) Accountability Appropriateness Education:2004) كما أنه توجد محاولات لوضع معايير خاصة بذوي الإعاقة في الدول العربية، ومنها قيام مكتب التربية والتعليم لدول الخليج العربي بإصدار النموذج التتظيمي للجودة

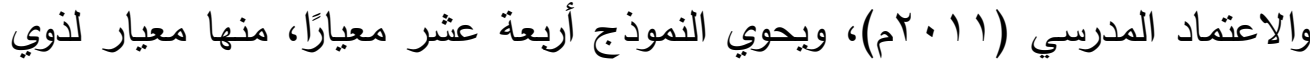

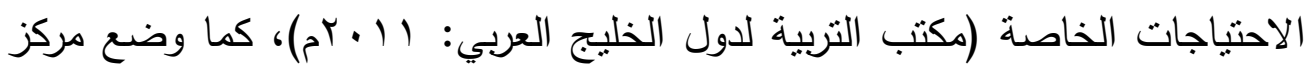
الملك فهر للجودة في المملكة العربية السعودية معايير لأفضل الممارسات في جودة التعليم المدرسي، ومنها معيار لذوي الاحتياجات الخاصة (مركز الملك فهد للجودة:

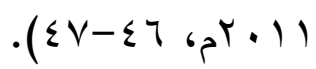

وتوجد أيضًا معايير المجلس الأعلى لشئون الأشخاص المعوقين في الأردن، وتتضمن معايير برامج التربية الخاصة ثمانية أبعاد هي: الروئية والفكر والرسالة، الإدارة والعاملين، البيئة التعليمية، التقييم، الخدمات والبرامج، مشاركة الأسرة، الدمج والخدمات 
الانتقالية، التقييم الذاتي (المجلس الأعلى لشئون الأشخاص المعوقين في الأردن: $\cdot()^{r} \cdot \cdot \cdot{ }^{2}$

وهذا يوضح أن التوجه نحو اعتماد برامج التربية الخاصة سوف يقدم حلوًا

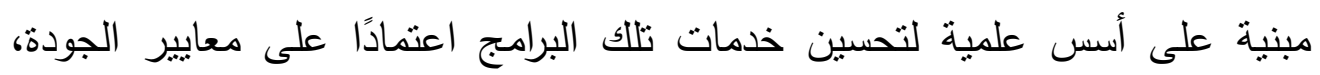
والتي تعد مطلبًا سابقًا للاعتماد التربوي لتلك البرامج.

\section{سادساً: فتح أبواب التعليم العالي لبهضغ الفثات المهمشة من ذوي الإعاقة}

يعد التعليم العالي دعامة أساسية لتتمية المجتمعات، وإعداد الإنسان الذي هو محور العملية التربوية؛ حيث يعد التعليم الأداة الفعالة لتتمية القوى البشرية واستثمارها،

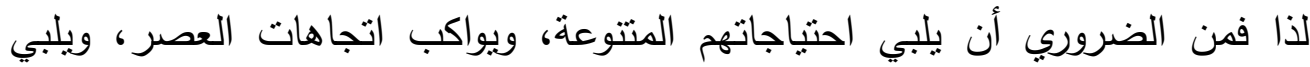
متطلبات الخطط التتموية، الأمر الذي يتفق مع أهداف نظرية رأس المال البشري، والتي نؤكد على أنه كلما ارتفع المستوى التعليمي للفرد زادت إنتاجيته ويتبع ذلك زيادة في الإنتاج الوطني. وتعد الفئات المهمشة من ذوي الإعاقة شركاء في التنمية، ولهم الحق منل أقرانهم العاديين في التعليم بصفة عامة والتعليم الجامعي خاصة. ويعد التعليم الجامعي بالنسبة لذوي الاحتياجات الخاصة ضروريًا، بل يفوق في أهميته الخدمات الأخرى المقدمة لهم؛ لأنه يمكنه من المعارف والخبرات التي تعينهم

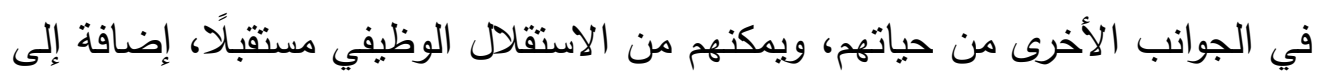

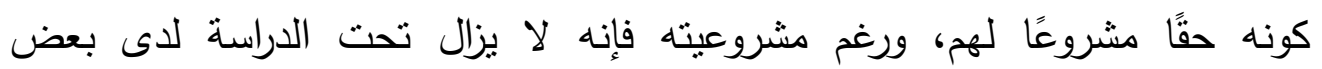
الجامعات أو بعض الجهات المسئولة عن التعليم العالي في بعض الدول العربية، وفي المقابل رأت بعض الجامعات قبول الطلاب الذين لا تحول إعاقتهم دون التحاقهم

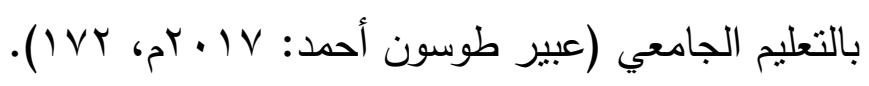

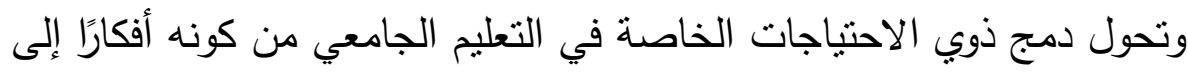
واقع يرى ويدرك بشكل منزايد نتيجة عمل المؤسسات الجامعية على تحقيق مبدأ تكافؤ 
الفرص والمساواة بين الطلاب العاديين وذوي الاحتياجات الخاصة (عبد الباقي عرفه:

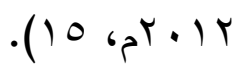

كما شهر مجال تربية الفئات المهيشة من ذوي الإعاقة عدة تغييرات تجاوزت مرحلة الحلم لتصل إلى مرحلة التنفيذ والتطبيق، وساهم في ذلك القوانين والتشريعات المختلفة.

فقد نصت المادة (؟؟) في البند الخامس من اتفاقية حقوق الأثخاص ذوي

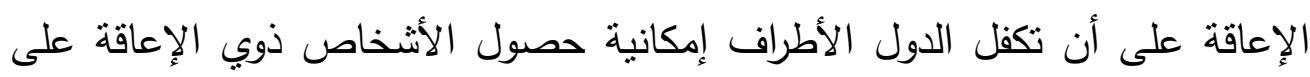
التعليم العالي والتدريب المهني وتعليم الكبار والتعليم مدى الحياة دون تمييز، وعلى قدم

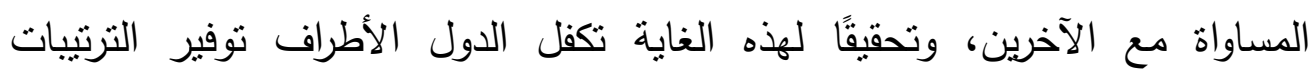

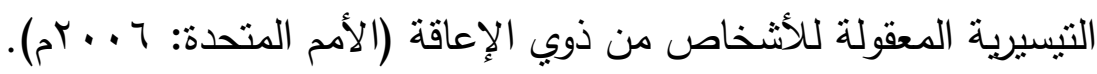

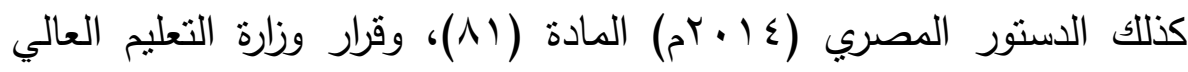
بجمهورية مصر العربية بشأن تفعيل نسبة اله\% المخصصة لذوي الاحتياجات الخاصة في تتسيق القبول بالجامعات، وتحديد قبول ذوي الإعاقة السمعية في كلبات التربية النوعية بأربع جامعات، والعمل على تطبيق الاتجاهات التربوية الحديثة والتي منها فتح أبواب التعليم العالي لبعض الفئات المهشة من ذوي الإعاقة لإكمال دراستهم

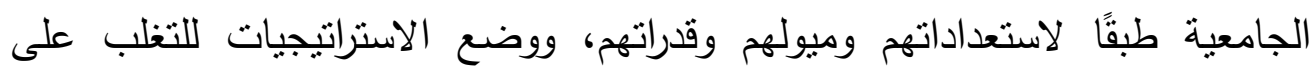
الصعوبات والتحديات التي تعوق مواصلة التعليم العالي، وتقعيل الخدمات المساندة والبرامج الانتقالية في تسهيل انتقال الطلاب من ذوي الإعاقة من المرحلة الثانوية إلى التعليم الجامعي أو المهني أو الوظيفي بكل سلاسة، ومحاولة بناء مجتمع جامعي أكثر شمولاً من خلال تكوين وتطبيق برنامج جامعي متكامل يعزز وينمي التتوع في الحرم الجامعي، ويتعامل مع القضايا المتعلقة بالإعاقات ورفع الوعي بها (علي عبد رب

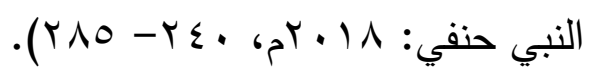

وعلى ذلك يمكن أن يكون هذا الاتجاه إضافة جديدة في مجال تربية بعض الفئات المهششة من ذوي الإعاقة، كما أن التوسع فيه وعدم اقتصاره على إعاقات معينة دون غيرها يمكن أن يؤدي إلى تتمية مهارات نلك الفئات، وتعزيز دافعيتهم لمواصلة 
التعليم العالي شريطة أن ينوافر التوجيه السليم، وتهيئة المناخ الجامعي المناسب بما يتلاءم وإمكانيات تللك الفئات.

\section{المهور الثالث: نتائج البمث، التصمر الاقثزح لثربية الفثات المهمشة بهصر في ضوى بعض الاتماهات المديثة، البموث الاقتزحة.}

يتتاول هذا المحور نتائج البحث، التصور المقترح لتربية الفئات المهمشة بمصر في ضوء بعض الاتجاهات الحديثة، والبحوث المقترحة؛ وذللك للإجابة عن التساؤل الثالث من تساؤلات البحث "ما التصور المقترح لتربية الفئات المهيشة بمصر بهر في ضوء بعض الاتجاهات الحديثة ؟".

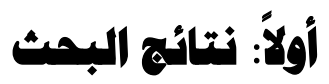
أسفر البحث عن مجموعة من النتائج من أهمها: 1- يعد مفهوم التهميش من أكثر المفاهيم صعوبَّة وتعقيدًا في مجال العلوم الإنسانية بصفة عامة والتربوية خاصة؛ لأنه يتضمن فئات عديدة يصعب حصرها والاتفاق عليها.

r- بطلق مفهوم الفئات المهشة على الفئات المستضعفة والأكثر احتياجًا والأولى بالتربية من الأطفال والثباب والمسنين والنساء، الذين يتم استبعادهم وحرمانهم من أي حق من حقوقهر خاصة الحقوق التعليمية، سواء أكان هذا الحرمان كلي من هذه الخدمات، أو أنها موجودة ولكنها قليلة وغير كافية، ولا تقدم بالثكل الذي يتلاءم واحتياجات هذه الفئات.

r- تتعدد الفئات المهيشة، كما أن الإحاطة بجميع جوانبها تتصدره مشكلات متعددة، تتعلق بنمط المعلومات المتاحة ونوعيتها ومعايير قياس التهميش ومؤشراته. ع- يعد التهميش التعليمي من أخطر أنواع التهميش والذي يؤدي بالطبع إلى حدوث جميع أنواع التهميش الأخرى. ه- يعد الاهتمام بتربية الفئات المهيشة من أهم المؤشرات التي يقاس في ضوئها تحضر الأمم وتقدمها. 
7- يعد إهمال تلك الفئات مشكلة اقتصادية واجتماعية وإنسانية لما لها من آثار سلبية على الفرد والمجنمع. V- يعد إلتحاق هذه الفئات بالنظام التعليمي وتمكينهم من النجاح والاستمرار فيه حقًا

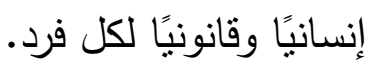
1- شهد القرن العشرين محاولات عديدة لتربية وتعليم الفئات المهشة خاصة من ذوي الإعاقة؛ وذلك من قبل الحكومات المتعاقبة والمنظمات الدولية والمحلية والجمعيات وليه الخيرية، والباحثين في مجال العلوم الإنسانية. 9- اهتمت مصر بهذه الفئات تشريعيًا؛ حيث أصدرت عديدًا من القرارات الخاصة بهر لكأخذ بأيديهم ومساعدتهم. • 1- على الرغم من الجهود المبذولة في تربية هذه الفئات إلا أنها لا تثتاسب مع أعداد هذه الفئات ومتطلبات توفير فرص التربية والتعليم المناسبة لظروف وإمكانيات هذه لرنه الفئات المهمة من نسيج المجتمع المصري بحضارته العريقة الممتدة لألاف السنين. 11- توجد عديد من الاتجاهات الحديثة في مجال نربية الفئات المهشة التي بدأت كثثر من الدول تطبيقها سواء على المستوى العالمي أو الإقليمي؛ وذللك في محاولة جادة لتوفير فرص تعليمية ذات جودة لهذه الفئات المهمشة من أبناء المجتمع. r إ- يعد التعليم الثامل أحد الإتجاهات الحديثة في مجال تربية الفئات المهمشة الذي هي يتطلب تهيئة البيئة المدرسية الداعمة له مع الاهتمام بتأهيل المعلمين في ضوء فلسفته وذلك قبل الخدمة وأثنائها. ب إ- على الرغم من التقدم الملحوظ في توظيف المستحدثات التكنولوجية في مجال تعليم بعض الفئات المهرشة - خاصة من ذوي الاحتياجات الخاصة- إلا أنه توجد

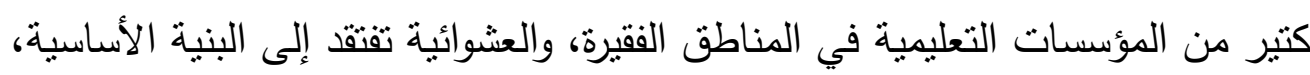
والتجهيزات الخاصة بالتعامل مع هذه المستحدثات وتوظيفها، كذلك قلة الوعي بأهمية تلك المستحدثات في هذا المجال. ع ا- تعد الخربطة التعليمية أحد أساليب التخطيط التربوي التي لها أهمية بالغة في وضع رؤية مستقبلية للفرص التعليمية وإتاحتها للفئات المهشة. 
10- يشير واقع المجتمع المصري لعدم كفاية الجهد الحكومي في مكافحة الفقر وصور التهميش المختلفة التي يعاني منها؛ لذا يوجد اتجاه قوي نحو دعم جهود مؤسسات المجتمع المدني، والاستفادة منها في مجال تربية الفئات المهشة بمصر . 7 ا- تزايد الاهنمام في العقدين الأخيرين من القرن العشرين بجودة مؤسسات التعليم بصفة عامة ومؤسسات تعليم الفئات المهمشة خاصة؛ وذلك لإحداث نقلة نوعية في منظومات العمل في هذه النوعية من المؤسسات بما يضمن جودة أدائها وتحقيق نواتج التعليم المستهدفة لهذه الفئات. V V - تعد الفئات المهرشة من ذوي الإعاقة شركاء في التتمية، ولهم الحق منل أقرانهم العاديين في التعليم بصفة عامة والتعليم الجامعي خاصة.

\section{ثانيا: التصور المتزح لثزبية الفثات الممششة بمصر في ضوء بعض الاتجاهات}

يقوم هذا التصور على مجدوعة من الأسس وببسىى إلى تحقيق بعض الأهداف من خلال مجموعة من الإجراءات التي تحدد ملامحه في ضوء بعض الاتجاهات الحديثة.

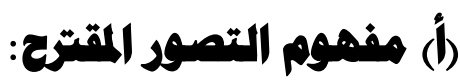

نظرًا لأن الفئات المهمشة جزء لا يستهان به من طاقة المجتمع المصري، وأن

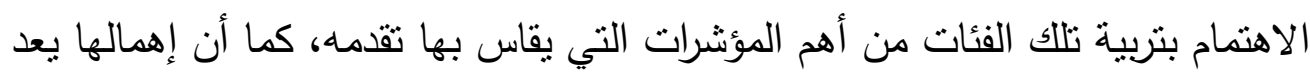
هدرًا بشريًا وإنسانيًا يصعب تبعويضه. لذا تتطلب الضرورة تقديم تصورًا مقترحًا لتربية الفئات المهششة بمصر في ضوء بعض الاتجاهات الحديثة. ويقصد بالتصور المقترح أنه إطار ونموذج يوضح كيفية تربية الفئات المهمشة بمصر في ضوء بعض الاتجاهات الحديثة. 


\section{(ب) أهمية التصور المتزح:}

$$
\text { تتمثل أهمبة التصور المقترح في الآتي: }
$$

1- أداة مساعدة في تكوين إطار منهجي يساعد في نربية الفئات المهشة بمصر في

$$
\text { ضوء بعض الاتجاهات الحديثة. }
$$

r- أداه لازمة لحث المسئولين عن التعليم في مصر على البحث عن صيغ التعليم المختلفة التي يمكن بها توصيل الخدمة التعليمية لهذه الفئات أينما وجدت. r- أداة فعالة في توضيح أهمية تجويد الخدمات التعليمية التي تقدم لبعض الفئات المهشةة، وكذلك إتاحة الفرصة للبعض الآخر لمواصلة تعليمه؛ الأمر الذي يتبعه زيادة إنتاجية تلك الفئات ومن ثم زيادة الإنتاج الوطني. ع - الاعتماد عليه في التتبؤ بطبيعة العلاقة بين تبني بعض الاتجاهات الحديثة في مجال تربية الفئات المهمشة، ومواجهة مشكلة التهميش التعليمي بمصر ، والتتبؤ بالنتائج المترتبة على الأخذ بهذه الاتجاهات.

\section{(c) فالمفة التصور الاقتزع ومنطhاتقاته:}

يعد التعليم هو الأداة التي يمكن بها للفئات المهمشة بمصر من أن ينهضوا

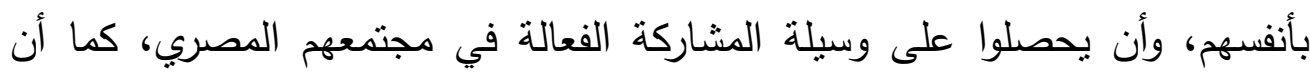
التهميش في التعليم يعد من أبرز المشكلات التي تواجها مصر، ذلك التهميش الذي لا يعني فقط الحرمان بمطلق العبارة؛ حيث تزداد هذه المشكلات مع عجز الحكومة عن توفير الخدمات التعليمية لتلك الفئات، وفي حال توفيرها لا تقدم بالثكل الذي يتلاعم واحتياجاتها.

لذا يتطلب الأمر البحث عن بعض المداخل والأساليب والصيغ التعليمية المختلفة التي يمكن بواسطتها توصيل خدمة تعليمية ذات جودة لهذه الفئات. إستنادًا إلى ما سبق بنطلق التصور المقترح من عدة منطلقات: 
ا- التتمية الثناملة التي ينشدها المجتمع بصفة عامة والمجتمع المصري خاصة لن

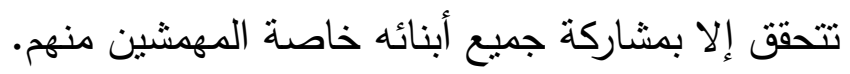
r- تتعاظم أهمية التعليم باعتباره حق عالمي لجميع الأطفال، كما أن الحرمان منه

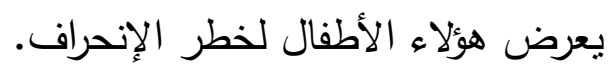

r- هناك بعض المداخل والأساليب والصيغ التعليمية المختلفة التي بدأت كثير من الأحراف الدول الأخذ بها وتطبيقها؛ وذلك في محاولة جادة منها لتربية هذه الفئات والنهوض بله بـا من هذه المنطلقات تتحدد فلسفة التصور المقترح الذي يسعى إلى نربية الفئات

$$
\begin{aligned}
& \text { المهيثة بمصر في ضوء بعض الاتجاهات الحديثة. } \\
& \text { (د) أسس التصور المقتزح: } \\
& \text { بؤسس التصور المقترح على عديد من الهرتكزات من أهدها: }
\end{aligned}
$$

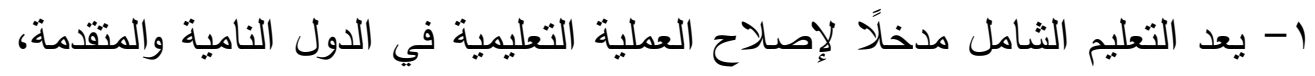
واستراتيجية أساسية للتعامل مع مصادر الإقصاء والتهميش والاستبعاد. r- تعد المستحدثات التكنولوجية فرصة لإحتواء الفئات المهمشة ورعايتها وإدماجها ضمن نسيج المجتمع، وتحويلها إلى عناصر منتجة وفعالة. r- يعد أسلوب التخطيط التربوي باستخدام الخرائط التعليمية أحد الاتجاهات الحديثة، التي يمكن استخدامها في رصد واقع الفرص التعليمية المتاحة لبعض الفئات المهمشة من ذوي الاحتياجات الخاصة، وأطفال المناطق العشوائية، والأطفال من سكان المقابر، وغيرها من الفئات المهشةة والمحرومة من التعليم، على مستوى القرى والمراكز والمحافظات، والذي في ضوئه يتم استتراف المستقبل، ووضع الرؤى المستقبلية لتوفير فرص التربية لهذه الفئات، وفي ضوء الظروف والإمكانات المتاحة والمتوقعة لكل منطقة. 
ع- تعد مشاركة جهود المجتمع المدني أحد الاتجاهات التي يمكن عن طريقها تقديم الخدمات التعليمية للفئات المهمشة والمحرومة من التعليم خاصة في الأحياء الفقيرة والمناطق الريفية النائية. ه- الاتجاه نحو اعتماد برامج ومؤسسات تعليم بعض الفئات المهشة يمكن الأطفال المهمشين من الحصول على فرص تعليم جيدة وذات جودة عالية، وهذا بدوره يساعد على الاحتفاظ بهذه الفئات داخل تلاك المؤسسات. צ- فتح أبواب التعليم العالي لبعض الفئات المهشة من ذوي الإعاقة، والتوسع فيه وعدم اقتصاره على إعاقات معينة دون غيرها يمكن أن يؤدي إلى تتمية مهارات تلك الفئات، وتعزيز دافعيتهم لمواصلة التعليم العالي، كما أنه يساعد على تحقيق مبدأ تكافؤ الفرص التعليمية والمساواة بين الطلاب العاديين والمهمشين من ذوي الإعاقة.

\section{(ه) أهد|ف التصمور الاقترح:}

في ضوء الفلسفة التي ينطلق منها التصور المقترح، والأسس التي يرتكز علبها، بيكن تحدبي الأهداف التالية: 1- تهيئة البيئة المدرسية المصرية الداعمة للتعليم الثنامل. r- دمج التكنولوجيا في العملية التعليمية، وتوظيفها في الوصول إلى الفئات المهمشة من التعليم بمصر والذين يصعب الوصول إليهم. r- استخدام الخربطة التعليمية كأحد أساليب التخطيط التربوي في نوفير الفرص التعليمية لبعض الفئات المهمشة خاصة في المناطق المحرومة والنائية بمصر . ع- دعم جهود منظمات المجتمع المدني في مجال تربية الفئات المهمشة بمصر • 0- الاهتمام بجودة عملية التربية بصفة عامة وتربية الفئات المهمشة خاصة. 
צ- دمج الفئات المهمشة من ذوي الإعاقة في الجامعات المصرية، وعدم اقتصاره على إعاقات معينة دون غيرها.

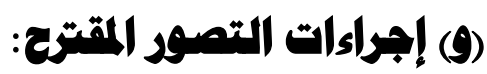

لتحقبق أهداف التصور الدقترح بتطلب ذلك مجدوعة من الإجراءات التي بيكن عن طريقها تربية الفئات المهشة بدصر في ضوء بعض الاتجاهات الحديثة، وتتمثل

$$
\text { هذه الإجراءات في الآتي: }
$$

1- صياغة التشريعات التعليمية الداعمة للتعليم الثامل، وتضمينها في قوانين التعليم. r- الأخذ بنظام الإدارة الذاتية للمدرسة من أجل الوصول إلى تمكين المديرين والمعلمين في المدارس، وأولياء الأمور والمعنيين بالعملية التعليمية في المجتمع المحلي من تحسين جودة المدرسة، ورصد التلاميذ المهشين والعمل على استيعابهم وتضمينهم في العملية التعليمية. r- نشر نقافة التعليم الثامل داخل المدرسة عن طريق عقد اللقاءات وإعداد النشرات لتوضيح أهمية تطبيقه داخل المدرسة. ع - الاستعانة بالكوادر المتخصصة في مجال التعليم الثامل لتقديم الاستشارات الفنية فيما بتعلق بتطوير الأداء المدرسي في هذا المجال. ه- تحديد الاحتياجات التدريبية للمعلمين والصعوبات التي يمكن أن نواجههم في ضوء فلسفة التعليم الثامل. 7- تدريب المعلمين حول فلسفة التعليم الثامل وأفضل الطرق للتدريس والتقويم، وتلبية احتياجاتهم في مجال التعليم الثامل. V- تضمين التعليم الثامل ضمن برامج إعداد المعلم في مرحلة التعليم الجامعي والدراسات العليا لزيادة وعي معلم المستقبل بمفاهيم التعليم الثشامل والجوانب المتعلقة 
ᄉ- تطوير المناهج الدراسية المقدمة لطلاب التعليم قبل الجامعي في ضوء فلسفة التعليم الثامل بحيث تتسم تلك المناهج بالمرونة لنلبية احتياجات الفئات المختلفة من الطلاب، تحفز على ثقافة تقبل الآخر، تدرب الطلاب على العمل الجماعي، اعتماد طرق تدريس تشجع على المناقشة وحرية التعبير والتفكير والاكتشاف منل: طريقة المناقثة والمحاكاة والعصف الذهني وحل المشكلات ودراسة الحالة. 9- تفعيل المشاركة المجتمعية لدعم التعليم الثامل؛ وذلك عن طريق توعية المجتمع المدني بأهمية تقبل تلك الفئات المهشة، وعقد بروتوكولات شراكة وتعاون لتحمل مسئولية تعليم تلك الفئات ودعمها. • - الاهتمام بالبنية الأساسية وإعدادها بعد أحد الأهداف الأولية لتوظيف المستحدثات التكنولوجية في مجال تربية الفئات المهشة، ولا تقف حدود التجهيزات الخاصة بالبنية الأساسية عند حدود الإنتاج فقط بل تمتد إلى توفير الإمكانات الخاصة بالتوصيل والعرض والاستخدام للأدوات والمواد المنتجة لخدمة هذه الفئات. 11- تخطبط المواقف التربوية والتعليمية السليمة التي تضمن توظيف هادف لهذه المستحدثات في تحقيق أهداف التربية والتعليم والتتمية المعرفية لهذه الفئات. r ا- تقدير احتياجات الفئات المهشة من المستحدثات التكنولوجية والاستفادة منها يجب أن يكون نابعًا من هذه الفئات نفسها، وليست تقديرات أو توصيات لمؤسسات أو أفراد لم يعايشوا مشكلاتها وحاجاتها. با ا- إنشاء هيئة عامة لتربية الفئات المهشة على نمط الهيئة العامة لمحو الأمية وتعليم الكبار على أن تمنل نلاك الهيئة على مستوى المحافظات والمراكز، يتم فيها دمج مهام الوزارات المختلفة في هيئة واحدة مستقلة تتبع رئاسة الجمهورية أو مجلس الوزراء مباشرة ويكون جزءً من مهامها حصر هذه الفئات وتوفير قاعدة بيانات كاملة عنها. 
ع ا- إنشاء إدارة للتخطيط تابعة للهيئة وممثلة على مستوى المحافظات والمراكز ، يكون من ضمن مهامها إعداد الخرائط التعليمية والتربوية لرصد الواقع الحالي للفرص التعليمية المتاحة لكل فئة من هذه الفئات والذي في ضوئه يتم استشراف المستقبل بوضع رؤى مستقبلية ببدائل متعددة يتم من خلالها اختيار البديل الأمثل في ضوء الإمكانات المتاحة لكل منطقة وحسب احتياجات كل فئة. 10- زيادة وعي المجتمع المصري على كافة المستويات (السلطة- المؤسساتالأفراد) بأهمية الدور الذي يقوم به المتمع المدني خاصنة في مجال دعم وتقديم الخدمات التعليمية للفئات المهشئة والمحرومة من التعليم. 7 ا - دعم جهود المجتمع المدني من خلال مراجعة القوانين والتشريعات التي تعيق عمل الجمعيات الأهلية والتأكيد على الدور التربوي لها في خدمة الفئات المهششة. V ا - توفير كافة الوسائل والآليات اللازمة لنجاح مؤسسات المجتمع المدني في تحقيق أهدافها، مما يساعد على نشر ثقافة التطوع، ويزيد من دافعية المواطنين على المشاركة في دعم ورعاية هذه الفئات.

1 ا- وضع قوانين وتشريعات جديدة تخدم الفئات المحرومة والمهمشة من التعليم. 9 ا - تشجيع الثراكة مع الجهات الداخلية والخارجية وهيئات التمويل الدولية في مجال تربية الفئات المهمشة. • r- إتاحة الفرصة لمشاركة الجمعيات الأهلية في وضع التشريعات والقوانين التي تتظم عمل منظمات المجتمع المدني في مجال التعليم بصفة عامة وتعليم الفئات المهيشة خاصة. ا Y- التنسيق والتعاون بين الجمعيات وبعضها البعض، وبين الجمعيات الأهلية وخبراء التربية في مختلف المؤسسات التربوية في تقديم الخدمات التعليمية للفئات المهيثة. 
r r- تزويد الجمعيات الأهلية بالمعلومات والبيانات المتاحة عن أعداد الفئات المههشة والمحرومة من التعليم كل في نطاقه. بr- تشجيع الجمعيات الأهلية على توسيع أنشطتها لتشمل أطفال المناطق العشوائية، والأطفال بلا مأوى، والأطفال من سكان المقابر ، وغيرها من الفئات المهشة. ع ب- نشر ثقافة الجودة والاعتماد داخل المؤسسات التي تقدم الخدمات التعليمية لتلك الفئات.

هr- التوسع في دعم جهود الهيئة القومية لضمان جودة التعليم والاعتماد لمساعدة كافة المؤسسات التعليمية الداعمة لتلك الفئات لتحسين جودة مخرجاتها من خلال آليات موضوعية وواقعية للتقويم الذاتي والاعتماد. جr- التوسع في فرص التدريب والتأهيل لكل العاملين في مجال تقديم الخدمات التعليمية للفئات المهشة والمحرومة من التعليم، بالتعاون مع الهيئة القومية لضمان جودة التعليم والاعتماد في مصر • V r - تحديد الأقسام الأكاديمية بالتعليم الجامعي التي تتلاءم مع قدرات وإمكانات الفئات المهيشة من ذوي الاحتياجات الخاصة. ^ץ- تعديل طرق التعليم الجامعي بما يتلاءم مع قدرات وإمكانات هذه الفئات. qץ- تطبيق برنامج جامعي متكامل يعزز وينمي التتوع في الحرم الجامعي، ويتعامل مع القضايا المتعلقة بهذه الفئات ورفع الوعي بها. • r- توعية الطلاب والأساتذة بطرق التواصل المختلفة مع هذه الفئات. اب- توافر أجهزة الأمن والسلامة في مؤسسات التعليم العالي والقاعات الدراسية. r r- تفعيل برامج الإرشاد الفردي والجماعي لتعزيز دافعية هذه الفئات لمواصلة التعليم العالي. 
r ب- تفعيل مكتب خدمات لهذه الفئات في الحرم الجامعي لضمان التواصل معهم من خلال تقديم الخدمات المناسبة لاحتباجات كل طالب بناءً على طبيعة إعاقته.

قالثا: البموث الاتمترحة

في ضوء نتائج البحث، والتصور المقترح، يقترح البحث الحالي إجراء الدراسات

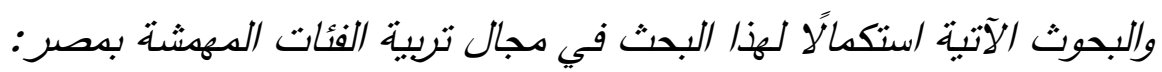

1- التعليم الثامل كمدخل لتربية الفئات المهيشة في مصر • r- تربية الفئات المهشة في مصر بين الواقع والمأمول.

ب- واقع الخدمات التربوبة التي تقدم لبعض الفئات المهمشة من ذوي الإعاقة بالجامعات المصرية. ع - تصور مقترح لتربية الفئات المهشة بمصر في ضوء خبرات بعض الدول.

\section{هـراجع البمث}

أولاًا: المراجع العربية

إبراهيم محمد إبراهيم (T + r م): "دور مؤسسات المجتمع المدني في تحقيق أهداف

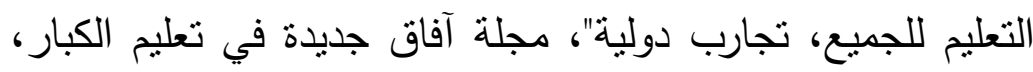
ع(飞)، تصدر عن مركز تعليم الكبار ، جامعة عين شمس، ص ص

$$
.01-r q
$$

أحمد الطيب محمد، حسين بشير، عبد المطلب أمين القريطي، محمد عطيه خميس

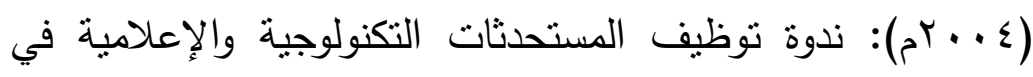
تعليم الفئات المهشةة، المؤتتر السنوي الثاني عشر بعنوان: "التعليم للجميع- التربية وآفاق جديدة في تعليم الفئات المهمشة بالوطن العربي"، في الفترة من ^r-q بارس، كلية التربية، جامعة حلوان،

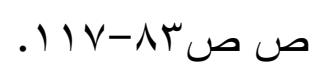

أميرة عبد السلام (1 ( • rم): "التربية وتمكين المرأة لتتمية المتمع"، مجلة كلية التربية،

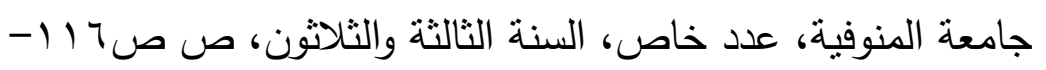


إيمان أحمد هاني محمود (^^..rم): الخربطة المدرسية لمدارس الفصل الواحد بمحافظة الشرقية" الواقع والاحتياجات المستقبلية"، رسالة ماجستير التهردية

$$
\text { كلية التربية، جامعة الزقازيق. }
$$

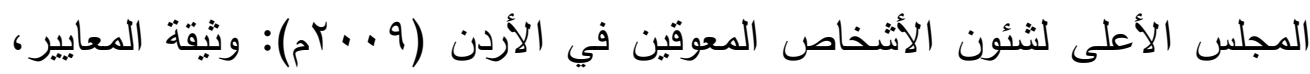
عمان.

المنظمة العربية للتربية والثقافة والعلوم ( . . بم): الاستراتيجية العربية للتربية السابقة على المدرسة الابتدائية، تونس.

الهيئة القومية لضمان جودة التعليم والاعتماد بالتعاون مع اليونيسف (ع ا ـ rم): وثيقة معايير ضمان جودة واعتماد مؤسسات التعليم المجتمعي، الإصدار

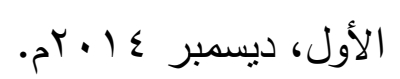

اليونسكو ( . . r م): التقرير النهائي للمؤتمر الإقليمي حول التعليم للجميع في الدول العربية، المؤتمر العربي الأول حول التعليم للجميع، القاهرة.

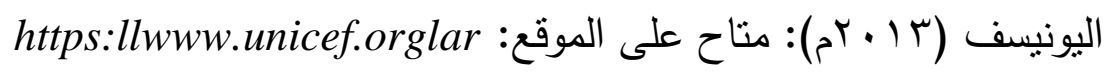

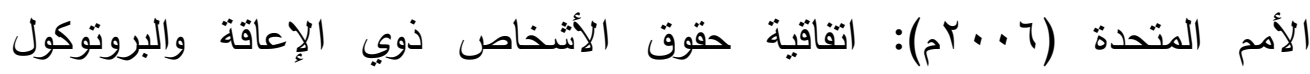

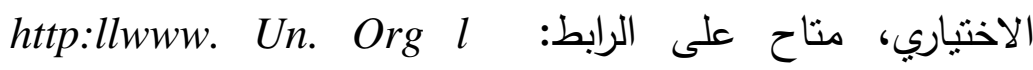
disabilities $l$ documents $l$ convention $l$ convoptport- $a$. $p d f$. جمال علي خليل الدهشان (1/ • rم): "توظيف تكنولوجيا المعلومات والاتصالات في رعاية وتعليم ذوبي الاحتباجات الخاصة"، مجلة كلية التربية، جامعة

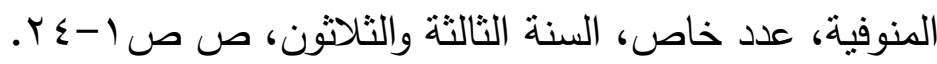

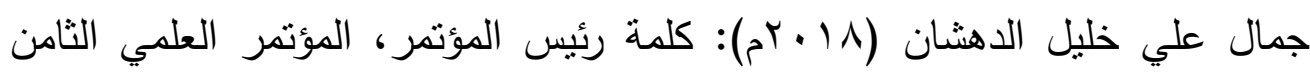

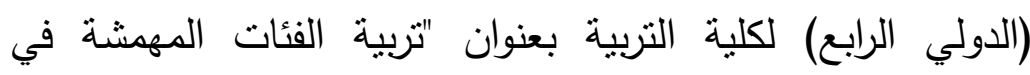

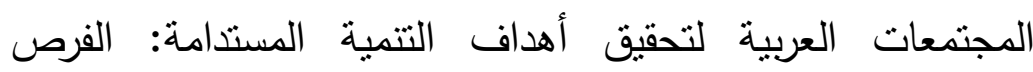

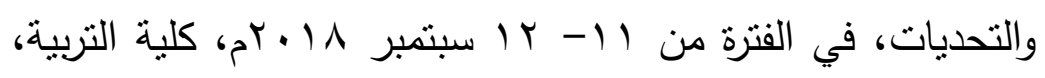
جامعة المنوفية. 
جمال علي خليل الدهثان، أماني محمد شريف عبد السلام (1 ا • بم): "دور الجمعيات الأهلية في تلبية الاحتباجات التعليمية للفتيات المهمشات من التعليم بمحافظة أسيوط"، مجلة كلية التربية، جامعة المنوفية، عدد خاص، الاصنا

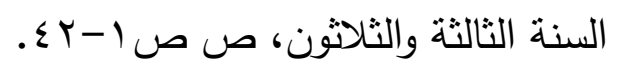

جمهورية مصر العربية، مجمع اللغة العربية (•99 (م): المعجم الوجيز ، القاهرة، طبعة خاصة بوزارة التربية والتعليم.

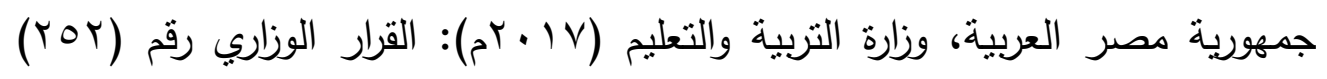

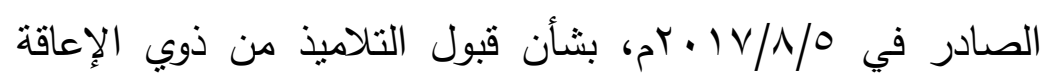

$$
\text { البسيطة بمدارس العليم العام. }
$$

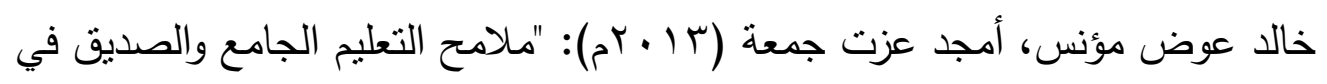
شخصية الرسول صلى الله عليه وسلم"، ورقة عمل مقدمة إلى اليوم

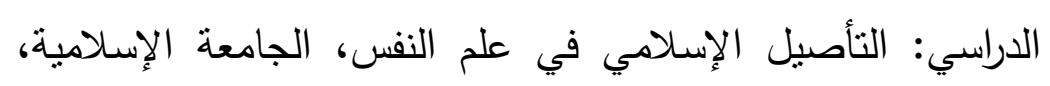

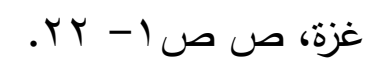

رانيا وصفي عثمان (1/ + r م): "متطلبات تطبيق التعليم الثامل لتمكين بعض الفئات المهمشة في مصر في ضوء تجارب بعض الدول"، مجلة كلية

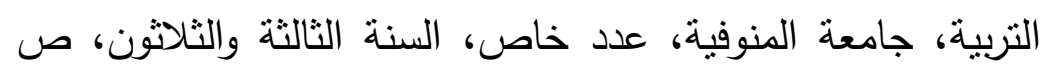

$$
\text { ص }
$$

رئيس الهيئة القومية لضمان جودة التعليم والاعتماد (10 • rم): أولوية لتعليم الفقراء

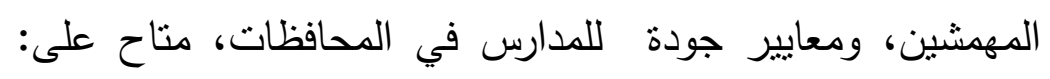
ahram. Org. eg

زينب محمود شقير (1 ( • rم): "الفئات المهيشة بين الرعاية والإهمال قديمًا وحديثًا"، مجلة كلية التربية، جامعة المنوفية، عدد خاص، السنة الثالثة

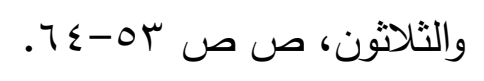

سعودي محمد حسن (r (r r)م): "دور الجمعيات الأهلية في الحد من التهميش الاجتماعي الموجه ضد المرأة المعاقة"، مجلة دراسات في الخدمة 


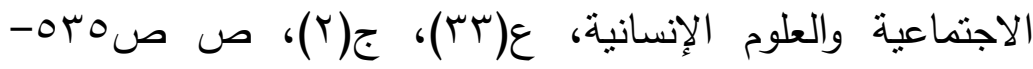
.017

سلامة صابر محمد العطار، سعيد محمود مرسي (11 • ب م): "الحق في التعليم مدخل لتوفير الاحتياجات التربوية للمهشين من أجل التتمية الثاملة"، مجلة كلية التربية، جامعة المنوفية، عدد خاص، السنة الثالثة

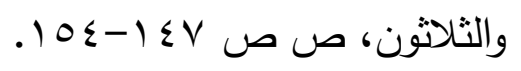

سليمان عبد ربه (ץ ..rم): "الجهود التربوية للجمعيات الأهلية في مصر"، مجلة التربية، جامعة عين شمس، السنة الخامسة، ع(7). (ج).

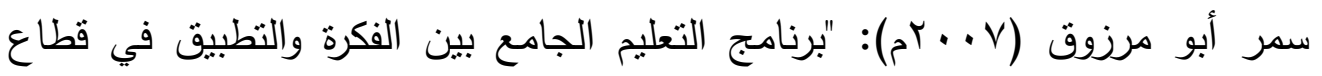
غزة"، ورقة عمل مقدمة إلى المؤتمر العلمي الأول بعنوان: التربية

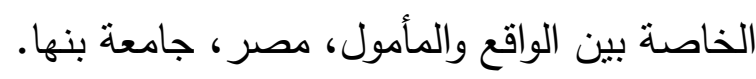
صبحي شعبان شرف (1 ( • rم): كلمة مقرر المؤتمر، المؤتمر العلمي الثامن (الدولي

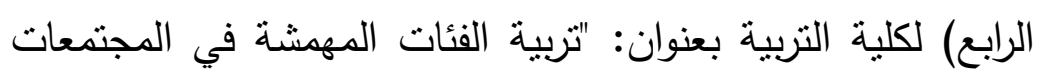
العربية لتحقيق أهداف التتمية المستدامة: الفرص والتحديات"، في برنه

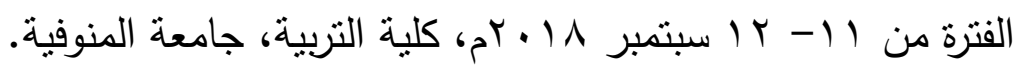
طارق محمد عبد الرحيم مهنا (1/ • rم): توظيف استراتيجية التعليم الجامع لدى مديري مدارس وكالة الغوث الدولية بمحافظات غزة وعلاقته برفع مستوى مانم الكفاءة المهنية للمعلمين، رسالة ماجستير، الجامعة الإسلامية بغزة، وهات عمادة البحث العلمي والدراسات العليا، كلية التربية. عاطف بدر أبو زينة (ع . . rم): "آليات تلبية المدرسة الابتدائية للاحتياجات التربوية والاجتماعية لطفل المناطق العشوائية"، مجلة التربية، تصدرها الائه

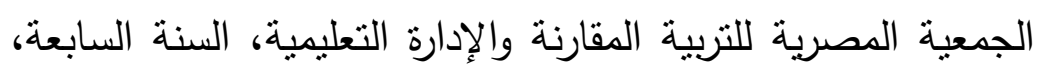

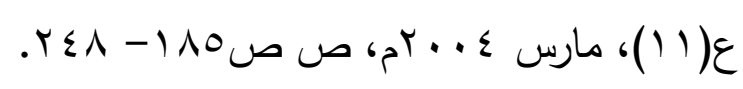
عبد الباقي عرفه (r ا • rم): نوعية المجتمع بفئات الإعاقة، مكتبة الأنجلو المصرية،

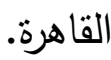


عبد العزيز عبد الله السنبل (r + . rم): التربية في الوطن العربي على مشارف القرن الحادي والعشرين، طا ، المكتب الجامعي الحديث، الاسكندرية.

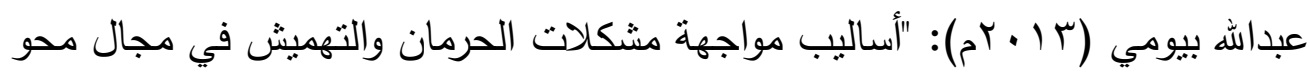

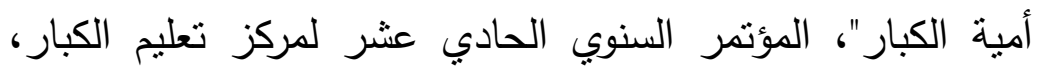
جامعة عين شمس، بعنوان "الارتقاء بتعليم الكبار في الوطن العربي

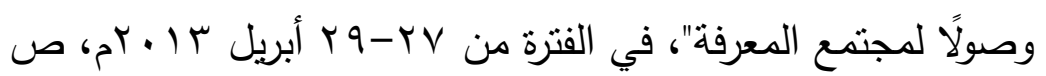

$$
\text { ص ص }
$$

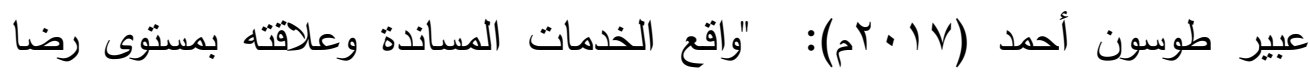
الطالبات ذوات الإعاقة البصرية عن الحياة الجامعية بكلية التربية-

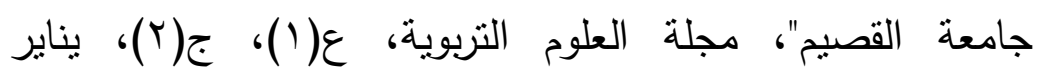

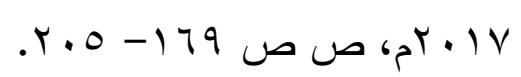

علي جبلي، آخرون (V +. r.م): "الفقر في مصر بين الاجحاف والإنصاف، رؤية مستقبلية"، المؤتمر التاسع، المركز القومي للبحوث الاجتماعية والجنائية، القاهرة.

علي عبد رب النبي حنفي (1/ • r م): "التعليم العالي لذوبي الإعاقة- الواقع،

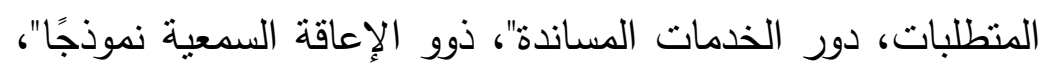
مجلة كلية التربية، جامعة المنوفية، عدد خاص، السنة الثالثة

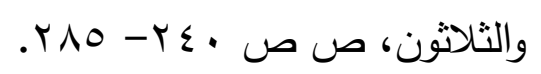

عمر مكي صغير ، ميساء علي الروابدة (r ( • rم): "رعاية السنة النبوية لذوبي الحاجات الخاصة والعامة"، مجلة الثقافة والتتمية تصدرها جمعية الثقافة من رئاء

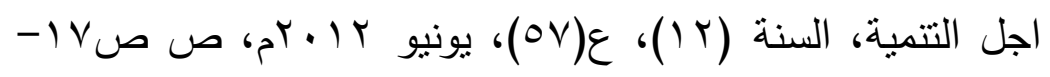
. فاطمة علي أبو الحديد (^ . . rم): أطفال بلا مأوى، دار المعارف، القاهرة. 
مازن العطل (T ( • Yم): درجة ممارسة معلمي وكالة الغوث الدولية بمحافظات غزة للمنحى الجامع للتعليم والتعلم وسبل تطويره، رسالة ماجستير، الجامعة الإسلامية، غزة.

محسن معوض (r ( r r): قضايا التهميش والوصول إلى الحقوق الاقتصادية والاجتماعية نحو مقاربات جديدة لمكافحة التهميش في العالم

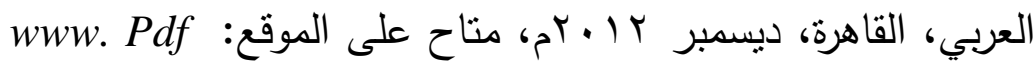
factory. Com محمد بن أبي بكر بن عبد القادر الرازي (§99 (م): مختار الصحاح، القاهرة، دار المعارف.

محمد سيف الدين فهمي ( . . بم): التخطيط التعليمي، أسسه، أساليبه، ومشكلاته، ط

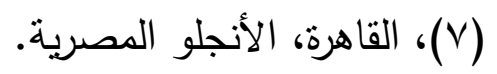

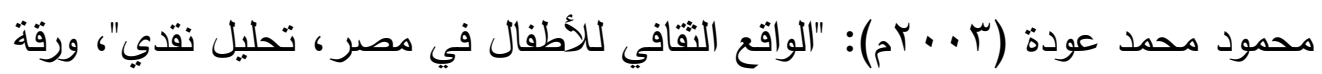
عمل مقدمة إلى المؤتمر الأول لنشبكة الحقوق التقافية لطفل العشوائيات مسئولية مجتمعية، قصر ثقافة الطفل، القاهرة.

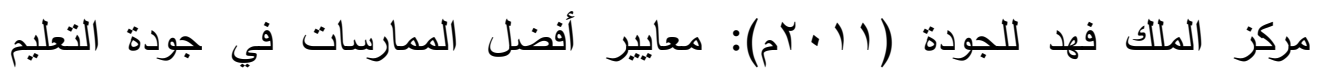
المدرسي، المملكة العربية السعودية، الإحساء.

مكتب التربية لدول الخليج العربي (11 +rم): النموذج التنظيمي للجودة والاعتماد المدرسي، المملكة العربية السعودية، الرياض.

منظمة الأمم المتحدة للتربية والعلم والتقافة (0 بم): مبادئ توجيهية بشأن التعليم الجامع، باريس.

منظمة الأمم المتحدة للتربية والعلم والثقافة (UNESCO): التقرير العالمي لرصد التعليم للجميع لعام . . . r-0 1 • rم" الإنجازات والتحديات".

منير عبد الله حربي (r +.rم): "دراسة تطبيقية في التخطيط المكاني لمركز كفر الزيات بمحافظة الغربية"، مجلة كلية التربية، جامعة طنطا، مج رج

$$
\text { (l.) ع ( ) ( ( ) }
$$


نادية حليم (ع ( • rم): "أطفال الثوارع المشكلة والحل"، المجلة الاجتماعية القومية، يصدرها المركز القومي للبحوث الاجتماعية والجنائية، القاهرة،

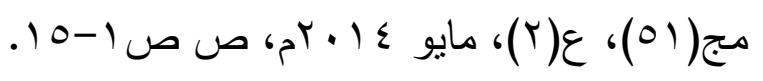

هانم خالد محمد محمد سالم (1/ • r م): "خريطة تعليمية مقترحة لتحقيق العدالة

التربوية لبعض الفئات المهمشة من ذوي الاحتياجات الخاصة

بمحافظة الثرقية"، مجلة كلية التربية، جامعة المنوفية، عدد خاص،

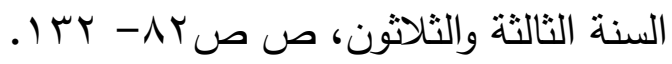

Dakar Framework For Action (2000): Education For All, Meeting our Collective Commitment: available at http:llwww2.

Unesco . Org l wefl en-con l.

Disability standards for Education In Asturalia (2005): Asturalia, Me. Donnelly, Verity (2010): Teacher Education For Inclusion-

International Literature Review, European Agency for

Development in Special Needs Education.

Falvey Mary a. And Givner Christine C. (2005): Creating an Inclusive Association For Supervision and School, $2^{\text {nd }}$ Edition,

Curriculum Development, available at http:llwww, ascd. Orgl publications l books 1105019 l chapters $l$ what-Is-an-inclusive-school \% c2\% A2. Aspx.

Hutter, Bridget\& O Mahony, Joan (2004): The Role of civil Society Organizations in Regulating Business. Discussion Paper No.26. London: The London School of Economics and Political Science.

Li, Yuejin (2012): The Role and Development of Grassroots NGOs in Eastern China". Master Thesis Submitted to Faculty of Social Science and Technology Management at Norwegian University of Science and Technology.

Gjovik: Norwegian University of Science and Technology.

Pospisilova, Tereza (2002): Grassroots Volunteering: Definitions,

Concepts and Themes. Overview of the Literature.

Brussels; European Commission. 
تصور مقترح لتربية الفئات المهمشة في ضوء بعض الاتجاهات الحديثة

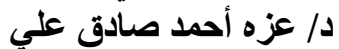

Special Education (2004): special Education- Alberta-standards for Handbooks, manuals, Edmonton, Alberta, Kanada.

The National Commission for the Accreditation of Special Education Services (2009): available at http:ll www.ncases. Org.

Unesco (2010): Higher Education in the Twenty-first century vision Action. Arab Region Conference on Higher Education, Beirut. 